\title{
Folk-Spectrum Music as an Expression of Alterity in 'Normalization' Czechoslovakia (1969-89): Context, Constraints and Characteristics
}

\section{Tom Dickins}

Anyone who spent time in Czechoslovakia in the 1970s and 1980s cannot fail to have been struck by the large number of young people carrying guitars and singing songs, which offered an escape from the ideological and artistic dogmatism of Communism. Music wilfully or otherwise played a key role in challenging the authoritative discourse of post-1968 'normalization'. Amongst the most influential genres at the time were three which form the basis of the current study: folk, country and tramping music (trampská hudba). (These closely related musical styles, which are defined later, are hereafter referred to collectively as 'folk-spectrum music'.) The aims of this article are 1) to set the music in its historical and cultural context; 2) to evaluate its reception by the ruling elite; and 3) to identify its salient lyrical and morphophonological characteristics, and the challenges that it posed to the status quo.

Pre-eminence is accorded to the lyrics, since they conveyed the overt cultural and socio-political 'message' of the songs. The content of the compositions articulated and embodied an alternative world-view, which stimulated people's imagination and raised their level of consciousness. Of particular importance in the creation of meaning were the songs' themes and linguistic construction. The lyrics, however, were only one of the defining elements of the folk-spectrum experience. The compositions derived their perlocutionary force (or overall effect) from a combination of the words and the music, as well as from the settings in which they were performed, and the way in which the artist(s) and the audience connected. ${ }^{1}$ The music that complemented the lyrics added significantly to the songs' appeal, and often remained in the mind long after the words had been forgotten. Similarly, the shared contextual dimension of the musical performance left a strong impression, which was sometimes more enduring than either the lyrics or the music.

The concepts of 'field', 'mode' and 'tenor', familiar through M. A. K. Halliday's systemic functional linguistics, provide a useful framework for the discussion of music as a language act. ${ }^{2}$ The three elements identified in his analysis of context are broadly interpreted here as follows: 'field' relates to the dominant ideas or tropes of a song; 'mode' to the channel of communication (written language sung to music), as well as to the genre employed (its rhetorical function); and 'tenor' to the interpersonal function of the text (the performers' adoption of personae, and the interactional aspect of their musical renditions). Within these terms of reference, musical get-togethers can be analysed at, at least, two different levels. First, the three concepts can be applied narrowly to the contribution of the artists themselves (that is, their compositions, together with their comments and anecdotes), and to the relationship that they established with the audience. Second, field, mode and tenor can relate more generally to the discourse that took place between the members of the public who sang or listened to songs together. The topics and details of their innumerable conversations are unknowable, but my personal recollections and other anecdotal evidence suggest that many were semi-subversive. The popularity of folk-spectrum music, as reflected both in packed auditoriums and in the sing-alongs in people's homes, pubs and various other venues, owed much to the fact that it provided a forum for exchanging information and presenting different perspectives. ${ }^{3}$

Appreciation of music is almost invariably more a reflection of common aesthetic and extra-aesthetic (especially social and psychological) impulses than the product of detailed textual or musicological deconstruction. ${ }^{4}$ The medium can both arouse the senses and create the impression of liberation from the everyday. As John Connell and Chris Gibson have pointed out, in respect of popular music in general, It provides one means, sometimes opaque, of reflecting or challenging social trends, attitudes to place, patterns of mobility and shifts in identity, enabling new identities to be forged through shared experiences in concerts, or simply through the shared lyrics, symbols and a common sense of style. ${ }^{5}$

Robert Gardner similarly picks up on the importance of the group dynamic of music: 'Though many of our music experiences are deeply intimate and private, listening to music is also a profoundly 
collective activity. ${ }^{6}$ Folk concerts and tramp gatherings (potlachy/sleziny), in particular, had a shared spiritually uplifting character. This is illustrated in Karel Plíhal's song about the creation of harmony, 'Akordy' (Chords), which alludes to both the communal and the spiritual aspects of music: celej svert je jeden velkej koncert lidských duši (the whole world is one great concert of human souls). The restorative effect of music is further evidenced in the slogan of the iconic annual Porta Festival (since 1972): Hudba je lék a Porta je nejlepši apatyka (Music is a medicine and Porta is its best pharmacy). ${ }^{7}$

Folk-spectrum music, whether viewed as a whole or in terms of its constituent parts, enjoyed widespread popularity, and was a poignant expression of alterity in a strictly regulated society. The defining features of the different styles varied, but each occupied an important position in what has been termed the 'grey zone' (šedá zóna) between consent and dissent. ${ }^{8}$ The music was a manifestation of and an influence on this indeterminate and slowly shifting 'space' between the minority of people who actively supported normalization and the (largely silent) majority who, to varying degrees, opposed it. It generally observed the unwritten rules of self-censorship, but it blurred the boundaries between mainstream and alternative culture, and it challenged the Communist Party's binary distinction between 'us' and 'them'. It existed both inside and outside the system and, as such, it was simultaneously condoned and condemned by the authorities.

On the one hand, most of the mainstream music was perceived as ideologically more or less acceptable, especially in comparison with other more radical cultural forms, such as rock music and punk. Much of it was, after all, more an expression of resignation than an act of overt opposition. It may even have been viewed by the Party as something of a safety valve, which helped to relieve the build-up of the pressure on the political system. On the other hand, it was difficult to regulate, and it subtly undermined the legitimacy of the official ideology. It also offered the opportunity for more direct contact between those who were publicly acquiescent, but felt little affection for the regime, and more vociferous critics of the socialist order. Evidence from the Security Services Archive (Archiv bezpečnostních složek) suggests that the StB (secret police) were often concerned as much by the company that the performers and their fans kept as by the compositions themselves. ${ }^{9}$

\section{Traditions and Context of the Three Genres}

Before considering in greater depth the evolution of folk-spectrum music, a brief definition of the terms of reference is required. All three genres (folk, tramping and country) are broadly conceived here to include those elements of 'popular' music which owe more to early twentieth-century Czech and European cultural heritage, as well as to American hillbilly, Western music, blues and gospel, than to other musical genres, such as brass band music (dechovka), disco, jazz, soul, and so forth. In Czech, 'folk' refers specifically to modern folk, rather than to traditional folk music (lidová hudba) (which was actively promoted by the Communist regime). ${ }^{10}$ While lidová hudba has informed the development of modern folk, at its heart are pre-war trampská hudba and American folk (especially Woody Guthrie). Modern tramping music is a mixture of elements of older forms of tramping music, American country, and modern and traditional folk. The term 'tramping' relates to the tradition of 'wild scouting' (that is, unregulated gatherings of young people, who seek to recreate the romanticism of the Wild West, accompanied by the sounds of country-style music). ${ }^{11}$ Czech country is heavily influenced by those aspects of tramping music which are rooted in American country, and belongs to the same narrative tradition. ${ }^{12}$ Both present similar simple sentimental themes, which depict mainly rural experiences, and appeal to basic emotional instincts.

Tramping, folk and country music each have a strong sense of their own identity and traditions, but they also have sufficient in common to be treated as a kind of loose entity. Indeed, as they contribute to a stylistic spectrum, it is sometimes difficult to observe a systematic distinction between them. ${ }^{13}$ They all share an accessible and unpretentious style, sometimes marked by the use of the colloquial idiom, and they all attribute high importance to the text. Musically, they are similar enough to take the same stage from time to time, as at the Porta Festival, which gave rise to the concept of the cross-over portovní žanr (Porta genre). The arrangement of the songs is beyond the remit of this study, but they all include patterns and structures which are memorable and easily recognizable. Country and tramping are more likely to have a collaborative dimension than folk compositions, although all three can involve audience participation. 
Tramping and folk songs employ traditional instruments (particularly the acoustic guitar, but also violins, mandolins, banjos, fiddles, etc.), while country music, at least in a formal setting, makes greater use of electric instruments (especially the guitar and drums). The three genres acquired much of their status and impact from their unique position in Czech culture. All three stood in contrast to other forms of music, and drew on the values, experiences and norms of the past, thematically, stylistically and conceptually. They were more experimental and varied than officially sanctioned pop; they were accessible to a broader cross-section of society (and less antagonistic to the regime) than rock, heavy metal and new wave; they allowed more scope for direct audience participation than jazz; and they posed a much greater threat to the official structures than classical or dance music. They may not have enjoyed the same acclaim as pop, but they appealed to a large number of people, who were united by a yearning for otherness outside the confines of the system. The real and 'imagined' communities which formed around folk-spectrum music were flexible, changing and noninclusive. Aficionados and casual participants came together in informal and formal gatherings, and opted in or out of the experience as they saw fit. Once trust between individuals had been established, the music was disseminated by means of bootleg recordings of private and public performances (rather than by Western-style air-play).

In order to appreciate the cultural significance of folk-spectrum music, it is necessary to have at least some knowledge of its intertextual and diachronic dimension. The success of the songs was attributable in part to the fact that they reconnected with an ill-defined earlier era that had been disrupted by Nazism and Stalinism. They tapped into a tradition in which culture had been central to the process of nation-building. Prior to the First Republic (1918-38), music had empowered people through a sense of common purpose. This shared 'lived' aspect of music is perhaps best reflected in the patriotic phrases co Čech, to muzikant (every Czech is a musician) and $v$ hudbě je život Čech i (the Czechs live for music). The notion of the past as another country where they did things better, to paraphrase the opening line of L. P. Hartley's The Go-Between, is constantly evoked by folk-spectrum music. ${ }^{14}$ After 1968, the mere act of listening to or singing a pre-normalization song evoked recollections of a more optimistic time in a happier land, when most citizens were united behind Dubček's reform programme.

The composition with the most poignant associations for many Czechs was Marta Kubišová's 'Modlitba Pro Martu' (A Prayer for Marta), recorded in 1968, which became the symbol of national resistance to the military occupation. ${ }^{15}$ The hit, banned in 1969 , owes its status to its allusion to the remark by John Amos Comenius (Komenský) (1592-1670) that one day people would once again decide their own fate: Ted' když tvá ztracená vláda věci tvých / zpět se k tobě navrátí, lide, navrátí (Now, when the governance that you once had over your own affairs / returns to you, people, it will return). Such was its impact that, when Kubišová performed it again in public twenty years later, the crowd was still able to join in with the words. Amongst the other songs embraced by the protesters in November 1989, which looked back with nostalgia, was Petr Skoumal's anthem, 'Neopouštěj nás (Svatý Václave)' (Don't abandon us [Saint Wenceslas]), composed in the late 1980s.

\section{i. Tramping music}

According to Jan Pohunek, the pre-war 'tramps' (trampové), sang a mixture of popular contemporaneous American and Czech hits, and more melodramatic pieces, including militarythemed songs which depicted the hard life of soldiers.16 Jaroslav Čvančara of the group Taxmeni suggests that Czechs first encountered American popular music during World War One, when members of the Czechoslovak Legion met American soldiers in the Russian Far East.17 Whatever the validity of this claim, tramping had its roots in pre-Communist times, and its adherents glorified in its anachronistic otherworldliness. It developed as a movement around 1918, alongside and out of the teenage Woodcraft movement, and in response to more formally structured and hierarchical organizations, such as the gymnastics association, Sokol, and the Boy Scouts (skauting/junáctvo). ${ }^{18}$ Petr Jehlička and Matthew Kurtz attribute great importance to the legacy of the Woodcraft culture, and claim the tramping tradition as its 'most popular strand'. ${ }^{19}$ 
The tramps have always consciously placed themselves outside mainstream society, and eschewed imposed cultural norms. They initially consisted of tightly-knit groups of 'friends' (kamarádi), generally working-class, left-leaning and anti-authority, who sought temporary escape from the strictures of urban life in wooded river valleys. They shared the fascination of the Woodcraft movement for the adventures of the Wild West, as depicted in popular fiction, Karl May's shilling shockers (rodokapsy), motion pictures (especially Tom Mix) and Zdeňek Burian's illustrations, but focused less on the rituals of the Indians. ${ }^{20}$ They wore distinctive Western clothing; reinvented themselves as pioneers with American-sounding nicknames; gave the surrounding geographical features new American-inspired toponyms, such as Velká řeka (Great River [= Vltava < Mississippi]); and established camp settlements (osady), to which they sometimes also applied North American names, such as Yukon and Utah. ${ }^{21}$

Music was at the heart of tramping. As Sparling and Pospísil have observed, 'The "tramping movement" might well have remained a limited and marginal phenomenon had it not been for its songs' ${ }^{22}$ The pre-war tramping songs tended to combine humour, sentimentality, romance and pathos, and often reflected the tramps' own experiences and love of the great outdoors. For example, the unofficial traditional tramping anthem, 'Vlajka vzhůru letí' (The Flag Flies High), written by Jenda Korda in 1929, has the opening lines: V̌se tone v snách a život kolem ztich / jen dole v tmách kol ohně slyšet smích / tam srdce všem jen spokojeně zabuši / z písniček známých vše jistě vytuši (Everything drowns in dreams, and life all around is silenced / Only in the depth of darkness round the fire can laughter be heard / There everyone's heart just throbs contentedly / And from the old songs can everything be perceived). This heady mix of sentiment and mystique persisted into the Communist era.

Following the harsh suppression of tramping from the late 1930s to the late 1950s, it re-emerged as a strong, more socially eclectic, non left-wing (but still anti-establishment) movement in the mid 1960s. It was given a new lease of life after 1963, when American Westerns were again permitted, and the hugely successful satirical musical film, Limonádový Joe aneb Koňská opera (Lemonade Joe or Horse Opera) was released. The fact that it re-established itself so readily suggests the strength of its cultural roots. Police harassment, sometimes quite severe, persisted throughout the 1960s, but the consequences for those apprehended were less serious. Tramps did not altogether abandon their former musical tastes but, to the annoyance of traditionalists, they adopted fresh approaches (often using more than one guitar), and embraced other musical genres, such as country, bluegrass, rock and roll (or bigbit [bigbeat]) and, increasingly, modern folk. ${ }^{23}$ A more accurate descriptor for the type of songs sung at their gatherings in the post-Stalinist period might thus be táborové písně (camping songs).

After the early 1960s, tramping music extended its appeal to a larger cross-section of society. Amongst the new generation of tramping groups and performers were Brontosauři (Brontosauruses) (started by Jan and František Nedvěd from the band Toronto, who were also members of the folk group Spirituál kvintet [Spiritual Quintet]), Pacifik (Pacific) (with Antonín ['Tony'] Linhart), Kapitán Kid (Captain Kid) and Stanislav Jan ['Wabi'] Daněk. ${ }^{24}$ Other bands which bridged the folk-tramping and/or country-tramping divide included Hoboes (headed by Wabi and MikiRyvola), Hop Trop, and K.T.O. or Kamarádi táborových ohňů (Friends of the Camp Fires). Several equally well-known names, including the country group Greenhorns, which was obliged to adopt the Czech title Zelenáči in 1972, similarly owed a great deal to the tramping tradition.

A turning-point in post-war tramping music came in 1975, with the release of Písné dlouhých cest (Songs of Long Journeys), featuring Pacifik, Hoboes, Kapitán Kid, Wabi Daněk and Brontosaurri. ${ }^{25}$ Daněk, whose work is sometimes described as 'folktramp', was perhaps the most influential of the tramping artists in the 1970s and 1980s. His fame rests principally on his sad signature song, 'Nevadí' (It Doesn't Matter) and his modern tramping anthem, 'Rosa na kolejích' (Dew on the Tracks), both released on the same album in $1984 .{ }^{26} \mathrm{He}$ is, however, also associated with more recent hits, such as his rendition of Miroslav Jaroš-Skunk's 'Montgomery (Jižní eskadrona)' (Montgomery [The Southern Squadron]) (strongly influenced by 'Just Before the Battle, Mother'). 
Travel and the discovery of 'new' realities became the leitmotifs of many of the tramps' songs and a preoccupation of their private lives in the 1970s and 1980s. The subject matter of the music simultaneously reflected and informed their discursive and behavioural practice. Large numbers of people would assemble in small groups for weekend trips to the countryside, dressed in green fatigues, with haversacks, mess tins, pocket knives and guitars, to escape the constraints of society through word and deed. Unlike their more conformist peers, who sought weekend sanctuary in private cottages, tramps redefined their relationship to space as an act of communitarian defiance. ${ }^{27}$ To be a tramp meant to subscribe to a distinctive sub-culture, based on a collective aesthetic and physical experiences - especially roving through woodland; sleeping in the open air (pod širákem), in tents or in shacks (chajdy); and singing, eating, drinking and smoking around bonfires. In the terms of the three elements of context employed in this study, the tenor (or interpersonal function of the musical phenomenon) was of primary importance. Thematically, the genre was less susceptible to criticism than folk, but its creation of a benign and exciting alternative reality (albeit one full of misconceptions), and the refusal of its devotees to conform to approved patterns of behaviour, rendered it suspicious. Moreover, the tendency of tramps to sing and listen to other more controversial folk-spectrum songs increased their untrustworthiness.

\section{ii. Folk music}

Modern Czech folk music, which came of age in the late 1960s, was the most eclectic of the three genres. Although it bore the strong influence of older musical traditions, it represented a conscious departure from the constraints of folklor, as well as a rejection of the optimism of the music of the 1950s and the Russian chastushka. Where folk performers drew on lidová hudba, as with Skiffle kontra, also known as Český skiffle and Žáci (The Pupils), and Minnesengři (Minnesingers), they tended to stylize it. Folk was an altogether more cerebral and reflective art form than folklór, tramping or country music, and it made significantly greater demands of its audience. In addition to appealing to its listeners' mental faculties, it foregrounded the addresser's own intellectual and emotional predispositions. In particular, it employed expressive prosodic and lexical features, accompanied by occasional verbal interjections, to draw attention to the performer's own relationship to the subject matter. There are clear parallels here with Roman Jakobson's 'emotive function', as outlined in his six communication functions, which focuses on the delivery of the message, rather than on the purely referential and cognitive. ${ }^{28}$

Other genres also left their mark on the folk music of the Communist period. Helena Pavličíková points out that artists such as Jaroslav Hutka, Petr Kalandra, Michael Janík and Vlastimil Třešńák were inspired by the environment of the rock scene of the 1960s, which was 'permeated with a desire for entirely informal expression and resistance to everything that was official'. ${ }^{29}$ This resistance was reflected not only in their musical tastes, but also in their non-conformist views and appearance (above all, their long hair). Folk was likewise shaped by the music of the Osvobozené divadlo (Liberated Theatre), and the work of Jiř́ Suchý and Jiří Šlitr, in the case of Jan Burian $;^{30}$ blues in the case of Vladimír Merta; and jazz, swing and blues in the case of Plíhal. Western protest songs, especially those by Pete Seeger, Donovan and Bob Dylan, had a profound impact in the 1960s. Seeger's acclaimed visit to Czechoslovakia in 1964 was of particular importance, although the focus of the Czech public was altogether different, as illustrated by the cool reception to his anti-American and anti-capitalist numbers. ${ }^{31}$

In the 1970s, folk music resonated mainly with the young and better educated, especially students, who were very much part of the system and behaved with due decorum at festivals and at concerts in clubs and student halls. By the 1980s, however, its audience had expanded considerably to embrace more of the general public. ${ }^{32}$ The permitted music did not directly challenge the legitimacy of socialism or eulogize capitalism. Nor did it contain inflammatory or abusive language. Yet, it was still considered potentially pernicious by the ruling elite because its sympathies lay outside the socialist system. It was never officially promoted, and state-controlled radio and television largely ignored it. Even well-established performers struggled to have their work released, although compilations from Porta were made available from 1967 to 1976 and from 1980 to 1989. 
Folk musicians exposed themselves to official censure through their refusal to compromise their integrity. They broached social themes with an honesty that was conspicuously absent from official discourse, and they focused primarily on urban experience, rather than seeking refuge in a rural idyll. ${ }^{33}$ Performers such as Merta and Jaromír Nohavica were held in especially high esteem, but they trod a fine line between acceptability and transgression. The authorities strongly suspected them of private opposition to the regime, and therefore subjected their every word to scrutiny. At best, their lyrics were interpreted as 'ambiguous'; at worst, they were condemned as anti-socialist. In a world where virtually everything was subordinated to Party doctrine, even the ostensibly apolitical acquired negative ideological proportions.

Mainstream folk in the normalization era owes much to the bands Spirituál kvintet, originally Spirituál kvartet (Spiritual Quartet), and Skiffle kontra, both founded in the early 1960s. ${ }^{34}$ Spirituál kvintet included (and includes to this day) Jiří Tichota, a trained musicologist, but folk is often associated with self-taught solo artists performing their own work. During normalization, these were mainly men in their twenties and thirties, although female performers, such as Dagmar AndrtováVoňková and Zuzana Navarová, also contributed significantly to the genre. ${ }^{35}$ Andrtová-Voňková's status was compromised in the mid-1970s through her association with the likes of Hutka and Vladimír Veit, although she was allowed to release several recordings in the late 1980s. In normalization Czechoslovakia, it was sufficient merely to be acquainted with someone who had left the country or had had political problems to suffer severe consequences in one's personal and professional life.

Perhaps the most thought-provoking and inspirational of the solo artists was Karel Kryl, nicknamed básník s kytarou (the bard with the guitar), whose poems sung to music were affectionately known as krylovky. Kryl's musical experiences were strongly influenced by tramping, but he came to the attention of the wider Czech public through the radio hit parade Dvanáct na houpačce (Twelve on a Swing), 1965-69. ${ }^{36}$ Kryl is possibly best-known for his 1965 release 'Anděl' (Angel), and his impassioned condemnation of the Soviet-led intervention, 'Bratřičcku, zavírej vrátka' (Little Brother, Close the Gate), both of which appeared on the same album in $1969 .{ }^{37}$ The latter included the line tato noc nebude krátká (this night will not be short), which became a catchphrase in its own right under normalization. Kryl emigrated in 1969, but his songs lived on in countless unofficial renditions, and through typed facsimiles and illicit recordings, which circulated widely. His broadcasts on Svobodná Evropa (Radio Free Europe), which played mainly emigre artists, also enjoyed widespread acclaim, despite the poor reception due to state jamming. ${ }^{38}$

At its most sophisticated, as exemplified by Kryl, Merta and Nohavica, folk was a challenging art form, which drew on a wide range of metaphysical, philosophical, literary and mythological sources. The field (or subject matter) and the mode (specifically the rhetorical function) were at least as important as the tenor in the context of this style of music. The compositions were firmly in the Western intellectual tradition, and represented an unambiguous revolt against the approved doctrinaire proletarian aesthetics. ${ }^{39}$ As Prokeš has pointed out, a fair number of folk songs were too conceptually demanding to be comprehensible to the wider public. ${ }^{40}$ To understand the symbolism and to decipher the codes of these songs required a degree of learning which many Czechs did not possess. Yet, that is not to say even the better educated listeners necessarily appreciated all their nuances and references. Nor is it to suggest that all the compositions were equally impenetrable, or that ordinary people could not derive pleasure from them. A song such as Hutka's 'Náměšt"' ([the town of] Náměšt'), which became the hymn of the Velvet Revolution, needs little formal education to be understood, and Nohavica's hit, 'Když mě brali za vojáka' (When I was Drafted as a Soldier), can be enjoyed without any appreciation of the cultural allusions.

\section{iii. Country music}

Like modern folk, country music constituted an alternative to the Party's authoritarian discourse, although it tended to be much more formulaic and prosaic. It dealt largely with experiences which had little to do with Czechoslovak society, particularly the stories of the Wild West. Sometimes these were seen through the eyes of an omniscient narrator or told from the perspective of the wandering cowboy (typically in the active voice, with little epistemic modality or exploration of alternative 
points of view). While devotees of the genre may have generally been less politically engaged than other folk-spectrum fans, they were well aware of its 'bourgeois' antecedents and its Western cultural referents. In their reality, the American myth substituted for the imposed Soviet myth. The parallels between the 'journeys' of the positive hero, who advances socialist progress through achieving political consciousness, and the 'good' lone ranger, who comes to embrace American social values, are more than superficial. ${ }^{41}$ Unlike Socialist Realism, however, American country music did not seek to effect social change, and it tended to avoid polemical issues (especially relating to discrimination).

A large part of the attraction of country songs, in common with tramping compositions, was that they represented a search for an alternative self through exotic trips to unknown spaces. The use of foreignlanguage sources, which were not widely available in the original, accentuated the exoticism, but where the lyrics were based directly on American sources, their writers usually 'interpreted' the original texts rather than merely translating them. This convention of 'interpreting' songs allowed access to otherwise restricted realities and mores, but limited direct contact with 'Western' languages (especially English), and provided opportunity for 'sanitization' of or improvement on the lyrics, where required. ${ }^{42}$ Paradoxically, however, the loss of the original cultural context of the compositions also resulted in the creation of new meanings, and permitted alternative readings of the words, which challenged the established norms in a way that they did not do in their source language. ${ }^{43}$

Country-style music thrived at festivals, at private parties and officially approved concerts, in clubs and pubs, and around bonfires and kitchen and dining-room tables. It had a broader fan base than either folk or tramping music, because of its greater accessibility, and its working-class origins, although many of its listeners and performers also embraced one or both of the other genres. Even some of the Czech country 'greats', such as Jan Nedvěd and the groups Rangers, forcibly renamed Plavci (Swimmers) in 1971, and Nezmaři (Indefatigables), were closely linked to folk and/or tramping music.

The normalization regime indicated its acceptance of country music as early as 1970 by sanctioning the release of the LP Písné amerického západu (Songs of the American West) (featuring Greenhorns, White Stars and Spirituál kvintet). Some popular country ensembles were even allowed to perform in capitalist countries, including Jiř́ Brabec's Country Beat with Nad’a Urbánková, and K.T.O. with Waldemar Matuška, in Nashville, in the 1970s. ${ }^{44}$ In 1978, Johnny Cash held a concert in Prague, and in 1980, Karel Gott recorded his Country Album, which further raised the profile of the genre. Such was the impact of the songs that many of the 'interpretations' of Western hits, especially those by Michal Tučný (the so-called král české country [king of Czech country]), Věra Martinová (první dáma české country [the first lady of Czech country]), Matuška, and Fešáci (Dudes), are better known in Czech to this day than they are in the original (with many Czechs probably unaware of their provenance). ${ }^{45}$

By the late 1980s, middle-of-the-road country music had lost some of its cachet, and had tended to give way to other sub-genres with more complex and spontaneous instrumentalization, especially bluegrass. Vondrak and Skotal have suggested that in the 1980s there were hundreds of bluegrass groups and dozens of festivals. ${ }^{46}$ Particularly worthy of note was the work of Robert Křest'an (who performed with Trapeři [Trappers] and Poutníci [Pilgrims]), whose hits included 'Napsal jsem jméno svý na zdi' (I Wrote My Name on the Wall), released in 1987. Country music did not represent the same overt danger to the regime as folk music or the tramping tradition. It was often more anodyne and fatalistic, and it did not pose such searching questions. Yet, it covertly promoted a non-political worldview through its disengagement from people's everyday experience. The interdiscursive dimension of country and tramping songs, with their romanticization of the Wild West, invited speculation about life far away, geographically, diachronically and ideologically, from normalization Czechoslovakia. The bitter-sweet sentimentality of American-style country also chimed with the Czechs' profound sense of regret about the fate of their nation. Aaron A. Fox has identified 'two competing, yet interdependent cultural metanarratives' in American country: 'Loss' (which turns 'things' into speaking, feelingful presences) and 'Desire' (which commodifies people and feelings). ${ }^{47}$ In the Czechoslovak context, 'Desire' was the search for private realization through the consumption of the unattainable, while 'Loss' was nostalgia for the old and the past. Just as important as the wistful 
and melancholic mood of the music was the forum that it provided for the sharing of alternative perspectives. As with tramping music, the tenor probably had a greater impact than either the mode or the field in terms of the challenge that it posed to Communist rule.

\section{The Authorities' Reception of Folk-Spectrum Music}

The Party hierarchy could only have looked on with envy at the genuine enthusiasm of ordinary people - often young and idealistic - who embraced folk-spectrum music. For most of its fans, this collective rejection of the imposed sterility of real socialism had few, if any, negative repercussions, and was a welcome diversion from everyday life. For musicians, however, who wanted to perform in public, self-expression came at a higher price. Virtually all artists, whether professionals who earnt a living from their music, 'independent' amateurs who made occasional guest appearances or, in exceptional cases, freelancers (na volné noze [literally 'on a free leg']), endured an uncomfortable relationship with the authorities. Those who fared best, such as Tučný, Brabec and Urbánková, tended towards popular music, although even they did not altogether avoid the opprobrium of the regime. ${ }^{48}$

\section{i. The regulation of music}

Amongst the well-known (non-underground) folk artists subjected to censure under normalization were Burian, Jiři Dědeček, Miroslav ['Slavek'] Janoušek, Nohavica, the Slovak Ivan Hoffman and even the working-class singer Pavel Dobeš (a Party member). Other well-established names more in the tramping tradition, such as Jaroslav Velinský (known as Kapitán Kid [Captain Kid]), also a popular science-fiction and detective writer, similarly faced official criticism. For example, his song, ‘Žádám' (I Desire), first performed in 1971, was forbidden on account of the lines Žádám, abych směl mít v oknech svýho domu / namisto mřiží rezavejch jen stín a větve stromů (I wish I were allowed just to have the shadow and branches of trees in the windows of my house, instead of rusty bars). ${ }^{49}$ Some of the most highly esteemed song-writers, including Daněk, spent years writing 'for the drawer' ( $d o$ šupliku), while much-loved artists, such as Kubišová, simply gave up singing in public.

The Husák regime undertook a series of 'administrative measures' (administrativní opatřeni) designed to weed out ideologically undesirable elements. ${ }^{50}$ The most important of these was the introduction, in 1974, of so-called requalification examinations (rekvalifikační zkoušky). According to Vaněk, these examinations comprised three parts: musical theory; a discussion of the social function of the musical discipline, together with a political 'conversation'; and a practical performance before a board appointed by the Party. Of the 6,475 artists invited to sit the first set of tests, only 3,450 were approved. ${ }^{51}$ The decision to blacklist or downgrade the professional status of a musician was always underpinned by ideological judgements, which took precedence over any artistic considerations.

Musicians who were granted a licence to perform were engaged in a constant struggle to find acceptable subject matter, which would extend the permissible. Self-censorship became a byword for survival. Folk artists, in particular, were regularly denied the opportunity to appear in public, and concerts were often rescheduled or cancelled at short notice. There were constant restrictions on where and when individuals and bands could perform, with different local organizations adopting a variety of practices. Where concerts did take place, frequently in small informal venues, it was often due to an oversight, an administrative loophole, or to the intervention of a local official. The situation tended to be worse in Prague than in the provinces, and it was especially bad in the late 1970s (after the launch of Charter 77 and the ensuing Anti-Charter movement). There was some improvement in the 1980s, particularly after Gorbachev came to power in 1985, but the picture remained patchy.

Opportunities for mass gatherings of fans and artists were more limited still, especially in the 1970s, with aspirant performers facing careful vetting. Even in the relatively more tolerant atmosphere of 1989, eighteen artists, including Merta, Nohavica, Pavel ['Žalman'] Lohonka and Marek Eben, were placed on a blacklist for Porta. ${ }^{52}$ That large-scale festivals, such as Porta and Folkový kolotoč (Folk Merry-Go-Round), survived at all is a tribute to the discipline and resilience of the folk-spectrum community. Great credit goes to the ingenuity and determination of their organizers, and to the authority of independent-minded music critics, such as Jiř́ Černý (who remained active despite being dismissed from his role in Czechoslovak radio). Equally deserving of recognition are the artists and the listeners, who largely resisted the temptation to use them as an opportunity for expressing 
discontent. Musical get-togethers were seen as ostrưvky svobody (islets of freedom) in an otherwise excessively regulated world, and self-restraint was a sacrifice worth making to ensure their continuation.

Perhaps the most overt challenge by folk-spectrum artists to the Communist authorities was the establishment in 1972 of the unofficial music association Šafrán (Saffron), comprising AndrtováVoňková, Burian, Dědeček, Zuzana Homolová, Hutka, Petr Lutka, Merta, Třešňák and Veit. ${ }^{53}$ The group of singers sought to promote artistic freedom, especially through public concerts and the release of vinyl recordings. Amongst the records produced in Czechoslovakia under the title of Šafrán was a single by Andrtová-Voňková, in 1976, featuring the tracks 'Chlapci na tom horním kopci' (Lads at the Top of the Hill) and 'Holoubek' (Dove), and an album with songs by members of the association simply bearing the name of the association - nearly all the copies were destroyed shortly after its release in 1977. Police persecution led to the disbandment of the association in late 1977 or early 1978, and ultimately to the emigration of Hutka (1978), Veit (1981) and Třešñák (1982). ${ }^{54}$ Other folk artists strongly opposed to the regime who were forced into exile included Svatopluk Karásek (1980), Dáša Vokatá (1980) and Charlie Soukup (1981). To some extent, the mantle of Šafrán was taken over by Sekce mladé hudby (Young Music Section), founded in 1977 under the Prague branch of the Czech Musicians' Union, and forcibly disbanded in 1985. However, the scope of its activities were more limited than those of Šafrán, and it lacked the influence of its better-known sister organization, Jazzová sekce (Jazz Section). ${ }^{55}$

The only form of musical expression that was not regulated in any way was underground music. Whilst most people were not actively involved in this branch of counter-culture, many were acquainted with banned songs, such as Jaromír Vomáčka's 'Běž domů Ivane' (Clear off Home, Ivan), recorded in 1968, or 'Miluju Sovětský svaz' (I love the Soviet Union), by an unnamed writer. The latter had the opening stanza: Já prodal jsem Forda, koupil jsem VAZ, I protože miluju Sovětský svaz. / Sovětský svaz, Sovětský svaz, / nenajdeš na něm pražádnej kaz (I sold a Ford, and I bought a VAZ / Because I love the Soviet Union. / The Soviet Union, the Soviet Union, / You won't find anything wrong there at all). Another more ironic song, which featured prominently in the Velvet Revolution, was Dědeček's trenchant response to perestroika, 'Vrat'te mi nepřítele' (Give Me Back the Enemy), written with great prescience in the mid-1980s. Amongst committed dissidents, musical tastes frequently went beyond folk-spectrum songs to include the work of groups such as Plastic People of the Universe and DG 307. The existence of such music did not, of course, directly threaten the power structures of the state, but it symbolically undermined the word of the ruling elite. Except where informers were enlisted, it was impossible to control expressions of opposition which existed solely outside the formal legislative structures.

\section{ii. Secret police surveillance}

In order to form a clear picture of the scope of secret police surveillance, I looked in depth at several of the StB files held by the Ministry of the Interior. In particular, I concentrated on the files relating to Kryl, because of his enduring influence on folk-spectrum music, and on five of the founder members of Šafrán - Hutka, Třešňák, Veit, Merta and Andrtová-Voňková. I also studied the files of two artists whose reputation has now been tarnished by revelation of their links with the secret police - Nohavica, who collaborated from 1986 to 1989, and Velinský, who was an informer from 1974 to 1989. Finally, I sought out documents relating to tramping, to establish the extent of StB involvement in their ventures.

The files on Kryl offer a detailed account of his decision to extend his stay abroad in 1969 without the permission of the Czechoslovak authorities, and of the legal measures taken against him in his absence. Kryl's emigration posed a major problem to the Communist regime because of his high profile in the West, and his continued links with his former compatriots, especially through his radio broadcasts. The files on Hutka, Třešňák and Veit serve to highlight their 'anti-socialist' activities, and present a justification for their prosecution and subsequent enforced exile. The cases of Merta and Andrtová-Voňková are more complicated, because neither was deemed sufficiently confrontational or oppositional to merit such drastic sanctions. Their files testify to their engagement in activities and their encounters with individuals perceived as contrary to the interests of the socialist state, but the 
measures against them stopped short of imprisonment or banishment abroad. Both Nohavica and Velinský appear in the StB files merely as agents, although it seems unlikely that Nohavica's short collaboration was especially significant. Velinský's activities may have compromised some of his fellow tramps, but I found no evidence linking him with specific repressive measures.

All members of Šafrán were rendered suspect by dint of their association with each other, as well as with other discredited individuals. As Lutka, cited in Třešñák's file, is said to have remarked, they all knew that the authorities were after them ('po nich jdou'). ${ }^{56}$ Hutka, Třešňák and Veit, in particular, made little effort to stay within the bounds deemed acceptable by the normalization regime. One informer notes of a concert by Hutka held in České Budějovice in November 1975: 'In my view, the whole performance by Jaroslav HUTKA was of an anti-state, anti-socialist nature [...] His songs have an ambiguous character, and in between songs his preamble is also of the same mindset. ${ }^{57}$ Another speaks of his invectives against official culture, and even against Husák, as well as of his 'inappropriate and crude vulgarisms' ${ }^{58}$ Perhaps most revealing in Hutka's files is the detailed analysis of his songs, which formed part of the legal case against him. ${ }^{59}$ Special significance is attached to his rejection of the sacred cows of socialism and post-1968 developments. For example, he is accused of mocking the Soviet Union in his popular song, 'Proč, proč' (Why, Why) through the lines Proč kozák jezdí na koni / no táto řekni proč / Středoevropský čas honi / proto proto brou noc (Why does the Cossack ride on horseback / well, daddy, tell me why / Central European time waits for no-one / that's why, that's why, g'night). ${ }^{60}$

More interesting still than the files of Hutka, Třešńák and Veit are those of Merta and AndrtováVoňková. Both performers are criticized for including ambiguities in their songs, which could be interpreted as slurs against socialism. Merta, who became a symbol of resistance, is condemned for dressing up his attacks on the regime as a protest against petty-bourgeois mentality and bureaucracy. ${ }^{61}$ $\mathrm{He}$ is depicted as a 'right-wing inclined songster' (praviciově zaměrený pisničkár), who appeals mainly to like-minded, free-thinking young listeners. ${ }^{62}$ Many of the documents stipulate that he be denied the right to artistic self-expression, but they also illustrate that he persisted with public appearances (often semi-clandestinely) throughout most of the normalization period. The files specifically acknowledge the extent of his popularity, and the range of his continued activities. ${ }^{63}$

Andrtová-Voňková's compositions are subject to very similar criticism. For example, one entry in April 1983 reads: 'In her concerts, she introduces songs, whose texts, which she herself writes and performs, are in conflict with the artist's guiding ideological principles in a socialist society. ${ }^{, 64} \mathrm{Her}$ alleged offences are non-specific, but they may have related to the dark tone of compositions such as 'Chlapci na tom horním kopci' and 'Holoubek'. By contrast, a more dispassionate expert evaluation of her work in December 1984 speaks fulsomely of her 'compositional and textual creativity', and her 'surprisingly brilliant, highly inventive, technically very progressive guitar play' ${ }^{65}$ In June 1986, Andrtová-Voňková was granted formal qualifications to perform again, and by the late 1980s, some of the restrictions placed on Merta were also relaxed.

There is comparatively little in the StB files relating to tramping or country music. Many of the 'incidents' involving tramps were dealt with by the uniformed police (VB). One event, however, which did merit secret police intervention was the planned hundredth anniversary celebration, in Český raj (Bohemian Paradise) on 17 January 1976, of the birth of Jack London (to whom the term 'tramping', in the current context, is generally attributed). The operation, under the codename Akce Tornado (Action Tornado), targeted tramps because of the overtly political character of the commemoration. There is only one reference to songs in the document, and nothing to suggest that they in themselves were seen as particularly polemical. ${ }^{66}$

\section{The Defining Characteristics of Folk-Spectrum Music}

This section of this article focuses on the concept of field, especially the themes, motifs, vocabulary and stylistic registers of folk-spectrum compositions. ${ }^{67}$ In order to identify the salient aspects of folkspectrum music, I drew up a corpus of songs, and adopted a discourse-analysis approach. The corpus ensures a reliable indication of recurrent features and vocabulary, while discourse analysis sheds light on language beyond the word and phrase level. Allowance is made for refrains and lexical items 
repeated for emphasis or poetic effect, which would otherwise skew the results, by counting frequency across, rather than within, the songs.

\section{i. Research parameters}

The study draws on a carefully selected sample of 240 Czech-language songs of all three musical styles closely associated with sixty individual performers, duets or groups, from before and throughout the normalization period. ${ }^{68}$ The number is intended to ensure thematic representativeness, without becoming unmanageable. Preference is given to compositions which were especially popular or influential in one way or another. Greatest attention is therefore paid to better-known songs by the leading exponents of each genre (folk - Spirituál kvintet, Kryl, Hutka, Karásek, Merta, Nohavica, Andrtová-Voňková, Burian, Dědeček, Plíhal, Janoušek; tramping - Brontosauři, Pacifik, Kapitán Kid and Daněk; country and bluegrass - Tučný, Martinová, Rangers/Plavci, Greenhorns/Zelenáči, Poutníci, Fešáci). One or two lesser-known tracks are also included, where they denoted a significant departure from the established norms. Several compositions from the 1960s are considered because they continued to enjoy popularity in the 1970s and 1980s, and thus still represented a major part of the rejection of the imposed cultural hegemony. A few well-known underground songs from all three decades are similarly listed, where their impact extended significantly beyond dissident circles. The corpus likewise contains a small number of pre-war tramping compositions, which continued to inform the tramping tradition, such as 'Kamarade drahý' (Dear Friend), 'Řeka hučí' (The River is Murmuring) and 'Vlajka vzhưru letí'. There are forty 'interpretations' of English-language songs and eight 'interpretations' of non-English-language songs in the corpus; that is, altogether, about 20 per cent of the total. ${ }^{69}$ The inclusion of compositions based on foreign sources seeks to reflect, very roughly, the balance that existed across the three genres.

\section{ii. Thematic and lexical features}

The discussion that follows is predicated on two propositions: 1) the theme, as the conceptual and organizing framework of each song, enjoys pre-eminence; 2) thematic unity across songs is achieved primarily through lexical repetition. Frequency tables provide the clearest indication of recurrent lemmas, and offer a scientific basis for prioritizing certain motifs over others. Yet, quantitative methods of investigation do not work equally well for all three styles of music. They are more applicable to stereotypical tramping and country songs than to folk compositions, which exhibit a greater range of lexical diversity and sophistication. Where possible, statistical data are used to support the arguments presented, but in the case of folk music qualitative approaches generally yield more meaningful results.

The schema below provides a summary of the major (sometimes overlapping) themes and motifs. It is not hierarchical, but love and infatuation (in all their manifestations and with all their ramifications), and travel (especially to the rural idyll), are by some margin the most common.

\section{PRINCIPAL THEMES}

\section{All three genres}

Love and infatuation

Adulation of women

Moravia

The passing of time

Suffering, despair and death

Music, poetry and dance, and the performer

Fictional nonsense, word-play and comedy

\begin{tabular}{|l|l|l|}
\hline Especially folk & Especially tramping & Especially country \\
\hline $\begin{array}{l}\text { Urban life and social } \\
\text { commentary }\end{array}$ & Nature and the & The cowboy \\
$\begin{array}{l}\text { Prison and justice } \\
\text { The triumph of morality } \\
\text { and the human spirit }\end{array}$ & & \\
\hline Especially folk and & & \\
\hline
\end{tabular}




\begin{tabular}{|l|l|l|}
\hline tramping & tramping & country \\
\hline Otherness and spiritual & Travel and escape & War and peace \\
togetherness & & \\
$\begin{array}{l}\text { Challenging the outdoor } \\
\text { tradition }\end{array}$ & & \\
\hline
\end{tabular}

I used the corpus analysis toolkit AntConc to identify statistically significant lexical items, and then selected the ones that had a bearing on my discussion below. ${ }^{70}$ (Function words and more general content words are excluded, as they add little to the argument.) The following table is not intended as a comprehensive word list, but rather as an overview of the most common relevant lemmas across songs. Synonyms are grouped together to save space.

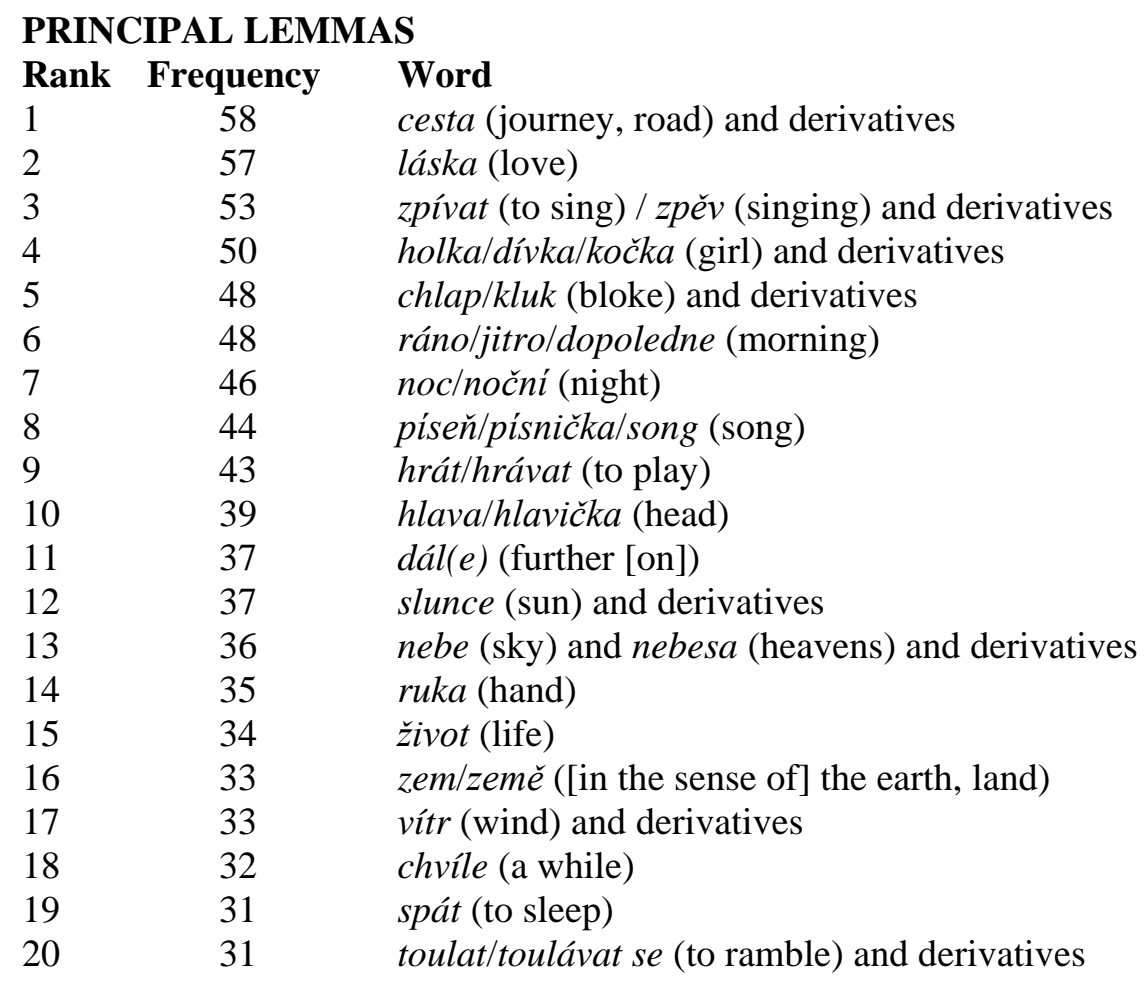

The theme of physical and emotional attraction is ubiquitous, as demonstrated by the use of the noun láska (love) in fifty-seven songs (nearly a quarter of the total). Unlike other areas of human experience, love exists largely independent of its socio-political setting (although it is framed by that setting). Most of the folk-spectrum songs are told from the perspective of the young heterosexual male, and many serve to eulogize women; see, for instance, 'Ženský ty jsou fajn' (Women are Great) (Karásek), 'Ješitný chlap' (Vain Bloke) (Brontosauři), and 'Píseň pro Kristynku' (Song for Kristinka) (Matuška), in which female beauty is depicted in terms of the aesthetic qualities of nature. At its best, romantic attachment gives a deeper meaning to human existence, especially in a society where the individual's scope for self-realization is restricted. This is suggested, for example, in the lines $V$ tomhle smutným světě jsi má nadějna víru / že nebe modrý ještě smysl má (In this sad world, you're my hope for believing / that the blue sky still makes some sense) in 'Růže z papíru' (Paper Rose) (Brontosauři). Where love fails or is unrequited, travel and/or the natural world sometimes provide an alternative source of sustenance, as in 'Vandrování' (Roaming) (Spirituál kvintet) or, from the female point of view, 'Až na vrcholky hor' (To the Mountain Tops) (Martinová).Women feature prominently in all three genres. The nouns holkal divkalkočka (girl) and derivatives are found in fifty different songs, and žena (woman) and its derivatives in twenty-two. (By contrast, chlap/kluk [bloke], and muž [man] and derivatives, appear in forty-eight and twelve, respectively.) From a contemporary feminist perspective, the country-style songs, in particular, sometimes seem reductivist and patronizing: ženy jsou krásný a cudný (women are beautiful and chaste) in 'Slavíci z Madridu' (Nightingales from Madrid) by Matuška, and višs, holky těžši to maj (you know, girls have it tougher), in 'Ptáčata' (Fledglings) by Brontosauři. 
They also fail to address more pressing social issues, such as the married woman's 'double burden', as home-maker and joint bread-winner, which was exacerbated by consumer shortages and bureaucracy. Yet, the compositions have to be seen in the context both of their time and place and of a musical genre where feminist values have been on the margin. ${ }^{71}$ It seems unlikely that women in the West would have embraced with equal enthusiasm a song such as 'Panenka' (Maiden) (Poutníci), released in 1987, which tells of the loss of a woman's virginity, and contains the lines Otevri oči ty uspěchaná, dámo uplakaná / otevři oči, ta hloupá noc konči a mír je mezi náma (Open your eyes, you flustered, tearful lady / open your eyes, this stupid night's ending, and there is peace between us). The compositions do not celebrate female subordination (à la 'Stand by Your Man'), but nor do they generally challenge the sexual status quo. Zdeněk Rytír's 'interpretation' of Willie Nelson's 'Good Hearted Woman', 'Baječná ženská' (Fabulous Woman) (Tučný), is an exception in that it pokes gentle fun at American country gender stereotypes. Instead of the male character being a 'good-timing man', he is an ideal partner - a 'fabulous bloke' (báječný chlap), who belongs firmly in the world of fable.

If love is the principal unifying 'private' focus of folk-spectrum music, travel is the main 'collective' focus of tramping and country music. Roughly the same number of songs broadly relate to each of the two themes - over one in four of all songs in the corpus in both cases. The 'long journey' was heavily influenced by the American country and western tradition, but also by sea shanties and other types of travel song, and it was frequently accompanied by reference to the sounds and accoutrements of music. In accordance with the findings of the cultural anthropologist, James Clifford, travel offered the opportunity for transformation through exploration and escape. ${ }^{72}$

The repetition of lexical items specifically relating to travel is striking. The noun cesta (journey, road) and its derivatives cestovni (travel) and cestovat (to travel) occur in fifty-eight of all the compositions in the corpus, and collocate with dlouhy (long) or dlouho (for a long time) in five of the songs. The adverb dál( $e$ ) (further [on]) is found thirty-nine times. Amongst the numerous verbs used to denote roaming are toulat/toulávat se (to ramble), bloudit (to wander), courat se (to trudge along), kráčet (to stride), loudat se (to saunter), rejdit (to gad about) and šlapat (to make tracks). Toulat/toulávat se and derivatives, toulavý (wandering), toulka (vagabondage), tulák (tramp), tulácký (vagrant), potulný (roaming), zatoulaný (stray), appear in thirty-one songs, while šlapat (to tread) and derivatives, prošlapat (to beat [a path]), prošlapaný (beaten), sešlapaný (worn-down) and boty-šlapky (women's shoes), occur in fifteen songs. The adjective toulavy collocates with boty (boots) and polobotky (low shoes) (cited in seventeen songs) in four compositions.

In tramping music the destination was generally the Czech countryside, especially river valleys, the forests and the mountains, reinvented as the Wild West. ${ }^{73}$ Pride of place in the modern tramping canon goes to Daněk's 'Rosa na kolejích', which includes the refrain Tak do toho šlápni / at' vidišs kousek světa. / Vzit do dlaně dálku / zase jednou zkus. / Telegrafní dráty / hrajou ti už léta / to nekonečně dlouhý / monotónní blues (So, step on it / and see a bit of the world. / Try once again / to take distance into your own hands. / Telegraph wires / have been playing to you for years / those endlessly long / monotonous blues). The fact that travel was severely restricted by the authorities, and Daněk's kousek světa rarely extended beyond Czechoslovakia, did not dampen people's wanderlust.

In country-style songs, there were virtually no limits to where the lyrical flights of fancy would take people - Alaska, California, Nashville, New York, Liverpool, Shanghai, and even to fictional places, such as Eldorado and the chimeric Golden Valley. As Sparling and Pospíśil note, 'Letting the listeners embark on imaginary journeys across space and time via country and western music posited a considerably lesser danger than letting them go in person and risk defections, should they get seduced by the glittering face of late capitalism' ${ }^{74}$ Usually the imaginary journeys were made either by train or on foot, but they also featured numerous other forms of transport, including bus, lorry, car, taxi, river boat, ship, horseback and stagecoach. With just two exceptions, distances are measured in miles rather than kilometres - the marked loanword míle is cited in eight different songs. 
The theme of the journey is also explored in more abstract ways in other songs. The ontological metaphor of the 'road' is central to Kryl's 'Morituri te salutant' (Those Who are About to Die Salute You), written in 1967, but released in 1969 on the album, Bratř́čku, zavirej vrátka. This work depends for its impact on the sophistication and subtlety of the images conveyed, rather than on its contribution to a lexically and semantically delimited subset of songs. Amongst the better-known lines, which acquired a particular resonance in the light of the Soviet-led occupation, were Cesta je prach a štěrk a udusaná hlína / a šedé šmouhy kreslí do vlasů (The road is dust and gravel and tramped earth / and it paints grey smudges in your hair). The anti-optimistic tone of Kryl's composition is likewise reflected in some of the later travel songs of Wabi and Miki Ryvola and the Hoboes, which are linked to the themes of the passing of time and death (also considered later). For instance, 'Tunel jménem Čas' (The Tunnel Named Time) concludes Ten konec moh bejt veselej, jen nemít tenhle kaz / tu černou díru kamennou - tunel jménem Čas... (The end could have been cheery, were it not for this flaw / this black stone hole - the tunnel named Time...).

In a similarly bleak vein, 'Mrtvej vlak' (Train of Death) offers the dubious reassurance Neměj strach, ve skalách zaduní mrtvej vlak / Chceš mit klid, máš ho mit, už jede vlak (Fear not, the train of death will rumble in the rocks / If you want peace, you should have it, the train is coming). Elsewhere, in 'Země tří sluncí' (The Earth of the Three Suns) and 'Drátěný ohrady' (Wired Enclosures), the Ryvola brothers focus on the freedom of birds in flight. The latter, written in the early 1980s, but first released on CD in 1992, includes the lines Jenom ten, kdo se nesmí vrátit / mysli denně na návrat / Drátěný, ohrady, drátěný / lidi děli od lidí / Když vraceji se domů ptáci / kluci tajně závidí (Only those who cannot come back / think daily of return / Wired, wired enclosures / Divide people from people / When the birds return home / the lads secretly envy them). The obvious allusion to the fate of Czechoslovak citizens, stuck behind barbed wire, but unable to go back to the land of their birth if they emigrated, was not lost on the fans of tramping music.

Followers of folk and tramping music had a common (if differently articulated) sense of alterity and spiritual togetherness. The tramps expressed their shared otherness by returning to nature, and by romanticizing or anthropomorphizing it in song, as in the collocation lesní moudrost (the wisdom of the wood), from 'Tulácký ráno' (Tramping Morning) (Brontosauři). ${ }^{75}$ Typical is the composition 'Osadní píseň' (Camp Settlement Song) (Brontosauři), which contains the lines Když měsic kraj ten ozář́ a peřej zašumí / tu kamarádi z osady si s lesem rozumí (When the moon illuminates this region [around the Sázava river] and the rapids murmur / here friends from the settlement are in communion with the forest). The fact that the rapids 'murmur', rather than 'roar', reinforces the reality that we are in Bohemia, not on the Hudson.

The call of the natural world, especially mountains and river valleys, is perhaps more strongly evoked than any other theme by the reiteration of referents in the same lexical field. Amongst the nouns which contribute to this semantic domain are zem and zemé (in the sense of the 'earth' or 'land') found in thirty-four compositions, tráva (grass), cited in twenty-five songs, reka/říčni (river) and ř́čka (rivulet), twenty-four, skála (rock, cliff) and skalnílskalnatý (rocky), twenty-three, les/lesní (wood, forest), seventeen, horalhorský (mountain, hill), also seventeen, údolí (valley), fourteen, pole (field), ten, and strán̆ (hillside), nine. Other less frequently cited topographical descriptors include pohoři (mountain range), sráz (steep hill), úboči (hill-side), balvan (boulder), šutr(ák) (rock), plán̆ (plane), bystřina (torrent), mělčina (shallows), potok (stream), vodopád (waterfall) and zátočina (river bend). Temporal, seasonal and elemental referents are also common. For example, ráno/jitroldopoledne (morning) appear in forty-eight of the compositions, noc/nočni (night) in fortysix, večer (evening) and derivatives in twenty-two, slunce (sun) and slunečni (sunny) in thirty-seven (including six as a collocate of pálit [to burn]), nebe (sky) and derivatives in thirty-six, vitr (wind) and větrný (windy) in thirty-three, and jaro/jarní (spring), often denoting rebirth and the start of the tramping season, in thirteen.

The essentially alien quality of the 'new' reality is highlighted by the inclusion of lexical exoticisms such as buš (bush), kojot (coyote), pampy (pampas), prérijelprérijní (prairie), ranč (ranch), slapy (rapids) and útes (cliff, reef). Its magical realism is accentuated by the use of colourful poetic collocation; for example, zlatý (golden) applied to nebe, pohoří, údolí, vodopád, déśt' (rain), and 
modrý (blue) applied to hora, les, skála, dým (smoke) and zář́ (September). The tramps were perfectly aware of the artificiality and theatricality of their invented world, and celebrated it in a series of songs, including Tramp (Brontosauři): Můžeš si myslet, že jsme blázni, / kteři si hraji na naivní svět. / Asi máš pravdu, pokud blázen / je láska lidi prostá jako květ (You may think we're mad people / who simulate a naive world. / You're probably right, if a madman / is the love of people, as simple as a flower). Their rejection of the space defined by real socialism is further evidenced by their selfdeprecating self-description in 'Generační' (Generational) (Brontosauři) as proradná banda bláznivejch lidí (a perfidious band of crazy people). Only occasionally are the compositions relating to nature more ominous in tone, as in Daněk's environmental protest song 'Stromy' (Trees), with its lines Proč misto lesa moje děti nechtěji navštívit I třeba skládku smetí? Těch máme dost (Why, instead of going to the forest, do my children not want to visit, / say, landfills? We have enough of them).

While the tramps found collective escape from the greyness of normalization through music in the wilds of the woods, folk devotees sought spiritual and aesthetic self-fulfilment mainly through public and private concerts in an urban setting. The thematic and lexical repertoire of folk singers was, however, broader than that of their country and tramping cousins, and sometimes included reference to the natural world. Amongst the folk songs depicting natural phenomena were Nohavica's 'Kometa' (Comet) and Janoušek's 'Halleyova kometa' (Halley's Comet), and Žalman's 'Jdem zpátky do lesů' (We're Going Back to the Woods). Perhaps the most striking composition in this category was Merta's 'Dlouho se mi zdá / Chtít chytit vítr' (It Has Long Seemed to Me / To Want to Catch the Wind), recorded in Paris in 1968 and inspired by the title of Donovan's 'Catch the Wind', which contains the repeated lines zabloudil jsem lhostejností, nevím jak najít cestu zpét (I have strayed through indifference / I don't know how to find my way back). The contrast with the 1950s' Communist slogan, Poručme vétru, dešti! (We will command the wind and the rain!) was only too transparent, but few at the time could have predicted that 'indifference' would become a byword for so many people's attitude to life in the 1970s and 1980s.

A handful of comic songs relating to nature and the outdoor experience mocked the tramping tradition. These compositions drew on the well-worn 'logos' of tramping, such as nüz (knife) and šerif (sheriff), to highlight the ritualistic nature of the activities. Most noteworthy were Kapitán Kid's 'Píseň proti trampingu' (Song against Tramping) and Nohavica's 'Píseň zhrzeného trampa' (Song of the Spurned Tramp). The former rues the discomfort and physical strains of tramping. The latter has the refrain Jájsem ostuda traperů / já mám rád operu / já mám rád jazz-rock / chodím posvětě bez nože / to prý se nemože / to prý jsem cvok / já jsem nikdy neplul našifu / a všem šerifüm jsem ř́kal Ba ne pane! / já jsem ostuda trempů / já když chlempu / tak v autokempu (I'm a disgrace to the trappers / I like opera / I like jazz-rock / I go round the world without a knife / something, they say, you should not do / I'm a nutcase, they say / I've never sailed on a river boat / and I've told all the sheriffs 'No way, mister!' / I'm a disgrace to the tramps / when I go boozing / it's at the caravan site). Other ironic takes on the walking theme included Třešńák's track, 'Zeměměřič' (Surveyor), recorded in 1978, about attempts to map the world, and Janoušek's 'Pochodové cvičení' (Route March), performed in 1989, but first released on audio CD in 1990, about children preparing for nuclear war.

Amongst the humorous Moravian-themed songs, pride of place goes to Mládek's 'Jožin z bažin' (Jožin from the Marshes, 1975). The composition tells of a mysterious monster who lives in the swamps and eats 'mainly people from Prague'. ${ }^{76}$ Specifically Moravian referents in the song include the river Morava and the town of Vizovice in eastern Moravia, as well as dédina (village [in Moravian Czech]) and slivovice (plum brandy [often drunk in Moravia]). Other light-hearted compositions, such as Hutka's 'Morava' (Moravia), also contain a range of regionally-specific allusions to create a strong sense of local identity. 'Morava' focuses on the principal attractions of Brno (the capital of Moravia) brněnská radnice (Brno town hall), Česká (the main street), Špilberk (the castle), Královo Pole (part of the town), and the two symbols of the city, brnénský kolo (the Brno Wheel) and brnénský drak (the Brno Dragon).

In contrast to the congenial tone of the songs about Moravia, several of the commentaries on urban life are quite caustic. Here, the compositions rely less for their impact on emblematic lexical repetition, and more on the socio-political implications of the lyrics. The best-known song in this 
mould is probably Hutka's 'Litvínov' (a town near Ustí nad Labem in north-western Bohemia), in which the interlocutor asks $A$ proč v tak nepěkných barácích bydlite / A proč tak zkažený vzduch tady dýcháte / A copo večerech, co tady děláte / Když slunko zapadne, kam spolu chodite? (And why do you live in such ugly blocks / And why do you breathe such rotten air / And what do you do here in the evenings / When the sun sets, where do you go together?). Nohavica's first public performances, in the early 1980s, occasionally included the song 'Blues o malých bytech' (Blues about Small Flats) an audacious critique of housing, public administration, jobs for the nomenklatura and restrictions on folk singers. The opening words must have resonated with large numbers of Czechs and Slovaks: Jak se tak zmenšujou byty a pokoje / no vážně / jak se tak zmenšujou byty a pokoje / je stále těžši těžši je stále těšši / dostat se do koupelny jen tak bez boje (The way flats and rooms are getting smaller / I'm being serious / the way flats and rooms are getting smaller / it is becoming harder and harder / just to get into the bathroom without a struggle).

In 1986, at Porta, Merta performed his astringent composition, 'Praha magická' (Magic Prague), which contained the lines Praho sídlišs' výkopů a věčných lešeni / kolébko, můj světe, vesmíre i vězení (O Prague of dug-up housing estates and unending scaffolding / my cradle, my world, the universe and prison). Janoušek presented a similarly negative interpretation of living conditions - the 'New aesthetics' (Nová estetika) - in 'Pohled z okna' (View from the Window), which first appeared on an EP in 1987: Dívám se nahoru z okna / Když dole je takovej bordel (I look up from the window / When it's such a bloody mess outside). The same year, he released his breakthrough album, Kdo to zavinil (Who's to Blame), including the track, 'Klukovské války' (Kids at War), which tells, in common colloquial Czech, of the degeneration of urban youth: Hele von je praštěnej ten borec / Si mysli že ho budem poslouchat když má kopi (Hey, that bloke is off his head / He thinks we're going to listen to him just because he's got a lance). The problem of misspent youth is further identified by Brontosauři in their 1987 release 'Stánky' (Kiosks), also in the colloquial idiom: U stánkủ na levnou krásu postávaj a smějou se času (They loiter around at the kiosks for a cheap thrill and they laugh at time). (The role and features of colloquial usage are discussed in detail in section 4.)

A sense of mournfulness and nostalgia for the past (Fox's 'Loss') permeates many of the songs in the corpus. While not anti-Communist in any strict sense of the definition, this melancholic mood is in stark contrast to the Party's panglossian vision of the future. It is perhaps most evident in the artists' preoccupation with the passing of time, which is evoked by reflection on disparate themes, each with their own lexical specificities. These include memories of childhood, the break-up of a relationship or the changing of the seasons. Illustrative of the theme are Daněk's 'Ročník 47' (People Born in '47), 'Slída' (Jody and the Kid) by Fešáci and Nohavica's 'Setkání s Puškinem' (Meeting with Pushkin). Towards the end of Communism there was much more discussion of transitoriness in the context of the changing values of society. This is evidenced, inter alia, by 'Pochod usmiřovačú' (March of the Appeasers) (Poutníci), performed in 1989 and released in 1990. The final verse, addressed to Hebe (the Greek goddess of youth), concludes včera už neni a dneska je zatím, / jó, časy se méní, ale dnes ještě platím, / jen žádný drama, to nebude lepší, / smiřte se s náma, smiřte se se vším... (It's no longer yesterday and it's today for the time being / yes, the times are changing, but today I'm still paying / just don't make a drama of it, it won't help things / make your peace with us / make your peace with everything...).

In other songs, the tone is more sombre still. Suffering, despair and death are found in all three genres. Again, the more reflective verse employs a greater range of imagery and conceit, and is less constrained by lexical convention. It varies in intensity from the darkness of, say, Kryl's 'Pasážová revolta' (Shopping Arcade Revolt) - Potlesk je $k$ umlčeni / a pískot na pochvalu / a misto presvědčení / jen pití piva z žalu (Applause is for silencing / and whistling for praise / and instead of conviction / there is just the consumption of beer out of grief) - to the helplessness of Daněk's 'Nevadí' - Vlaky jedou dál / a málokdy se vrátí, / život nemá brzdu / záchrannou (The trains keep going / and rarely do they return / life does not have / an emergency brake). The phrase nevadí, which tends to connote resignation rather than a philosophical acceptance of the status quo, occurs in seven different songs. A sense of alienation and isolation pervades several of the compositions, including Hutka's 'Pravděpodobné vzdálenosti' (Probable Distances) and Tučný's 'Snídaně v trávě' (Breakfast in the Grass < 'Sea Of Heartbreak'). Elsewhere, the very titles of songs, such Kryl's 'Rakovina' (Cancer) 
and Třešňák’s 'Tovaryš pátera Koniáše' (The Journeyman of Father Koniáš), sets them apart from the officially sanctioned mainstream. ${ }^{77}$

Amongst the most striking tracks to condemn the occupation is Merta's 'Hodina vlka' (Hour of the Wolf), in which a girl clad in mother-of-pearls is transformed into one of the aggressors: A ty přicházíš / sedíš na tankua nikdo tě nevidi / Otevíráš náruč a střilíš do lidí / Svlékáš se přede mnou I nikdo ti nepřináši květiny / Vrhášs se z letadla a počitáš vteřiny / Máš na rameni vránu smrti / a uniformu z perleti (And you come / you sit on a tank and nobody sees you / You open your arms and shoot into the people / You undress before me / nobody brings you flowers / You fling yourself from the plane and count the seconds / You have the crow of death on your shoulders / and a uniform of mother-of-pearls). Less overtly despairing, but no less politically pessimistic, was Nohavica's 'Mávátka' (Hand Flags), written in 1981, but released in 1986: Říkaji mi - dobráci v Rudém právu:/ Neni tak zle, jen, chlapče, zvedni hlavu! / Dejte mi do ruky mávátko a řekněte, jak volat Sláva! I Já už si najdu ten správný smér / a budu mávat, mávat, mávat! (Those kind souls in [the Communist daily] Rude právo tell me: / It's not so bad, guy, head up! / Give me a hand flag to hold and tell me how to shout Hurrah! / I'll find the right direction by myself / and I'll wave, wave, wave!). The authorities came to accept some expressions of resigned pessimism, but were much less sanguine about anger and discontent.

The question of human justice is touched upon in numerous songs. Prison is referred to specifically in ten compositions, not just by the formal terms vězení/věznice and colloquially kriminál, but also by the more slangy expressions, basa and lapák, and by the name of Prague's notorious jail, Pankrác. Occasionally, justice is treated as a theme of light relief, as in Tučný's, self-referential 'Pověste ho vejš' (Hang Him Higher), released in 1983. More often, its associations are negative, as in Hutka's poignant 'Havlíčku, Havle' (Havlíček, Havel), written in 1977 in honour of Václav Havel. Hutka's song, which was later closely associated with the Velvet Revolution, is best known for its catchy refrain A podle litery paragraf - šavle / ted' dumej o právu, Havličku, Havle (And by the letter of the law, article Sabre / now ponder over the truth, Havlíček, Havel). The addressee may have been clear to most who heard it, but Hutka defended the lyrics under interrogation by the StB by saying that it referred to the Czech writer and thinker Karel Havlíček Borovský, who in 1855 was exiled to Brixen (mentioned in the final verse). ${ }^{78}$ Perhaps the most powerful critique of the abuse of power and its dehumanizing effects is Kryl's 'Veličenstvo kat' (His Majesty, the Executioner), released in 1969: $S$ úšklebkem Dábel vidèl / pro každého podíl / Syn otce nenáviděl / Bratr bratru škodil / Jen motýl Smrtihlav /se nad tou zemí vznáši / kde v kruhu tupých hlav / dlí - veličenstvo KAT (The devil saw with a grin / each taking his part / The son hated his father / And the brother hurt his brother / Only the death's-head hawkmoth / soars over this land / where in the circle of the dull-witted / dwells his majesty, the EXECUTIONER).

The theme of war is prevalent in country and folk songs, as exemplified by the nouns válka (war) and voják (soldier), cited in thirteen and eight songs, respectively. Unlike much of the officially endorsed music of the time, the compositions tended to deromanticize armed combat. Several of the country songs relate to the American Civil War, including Tučný's humorous 'Buráky' (Peanuts) (influenced by 'Goober Peas'), which debunks the heroism of military service (Zeptaji se: 'Hrdino, cos dělal za války?' / Flákal jsem se s kvérem a loupal buráky [They'll ask: 'Hero, what did you do during the war?' / I loafed around with a rifle and shelled peanuts]). Others, such as Tučný's 'Blízko Little Big Hornu' (Near Little Big Horn), belong to the cowboy canon. Whereas the depiction of war in country ballads is often emotionally detached, in folk song it is much more personal and painful. Representative of the folk genre are Nohavica's version of Vian's 'Le deserteur', 'Pánové nahoře' (Gentlemen in High Places), and 'Když mě brali za vojáka': Když mě brali za vojáka / stříhali mě dohola / vypadal jsem jako blbec (When I was drafted as a soldier / they cropped my hair close to the skull / I looked like an idiot). Even more acerbic is Kryl's 'Píseň neznámého vojína' (Song of the Unknown Soldier): Co tady čumite? Vlezte mi někam! / Copak si myslite, že na to čekám? / Co tady civite? Táhněte domů! / Pomníky stavíte, prosím vás, komu? (What are you gawking at? / Get stuffed! / What do you think - that I'm waiting for it? What are you gaping at? Bugger off home! / You build memorials; to whom, please?). 
Another topic characterized by considerable lexical and stylistic diversity is faith and religion. ${ }^{79}$ Spiritual motifs and baroque symbolism are especially common in the folk music of the 1960s and 1970s, and serve primarily as a counterbalance to the secular world of Communism. Particularly striking are the religious images used in Kryl's work, such as 'Anděl' and 'Pieta', which elevate his texts above the banality of the everyday. Where religion is the principal focus of the discourse, folk songs generally reject conventional Christianity, and highlight, instead, the ethical aspects of belief; see, for example, Karásek's 'Řekni d'ablovi ne' (Say No to the Devil). ${ }^{80}$ Karásek is especially damning of the hypocrisy of organized religion and its adherents, as evidenced by 'Vy silní ve viře' (You Who are Strong in Faith): Vy silní ve víre, / v Písmu kovaný: / Když začnou bít Pastýře, / kde jste schovaní? (You who are strong in faith, / well-versed in the scriptures: / Where are you hidden / when they begin to beat the Pastor?). Such were the constraints on religion under normalization that it informed little of the more mainstream music. Even where the religious dimension was central to the original version of a foreign-language song, the Czech interpretation tended to downplay it, as in Spirituál kvintet's 'Dvě baby' (Two Old Women < 'I Can't Feel At Home').

Although questions of faith may not be the primary concern of most artists, morality and the human spirit are important leitmotifs in folk song, in particular. Many of the compositions have a strong ethical dimension, including 'Modlitba pro Martu', 'Náměšt'" (Mocná je zbran̆, mocnější je právo / Co je nejmocnějši, co je nejmocnějši, pravdomluvné slovo [The weapon is powerful, being in the right is more powerful / What is most powerful, what is most powerful, is the truthful word]), and Ivo Jahelka's 'At' žije spravedlnost' (Long Live Justice). The search for authenticity and justice were accentuated in the late 1980s, especially by performers such as Petr Skoumal, whose songs included 'Poločas rozpadu' (Half-Life), released in 1990: Nezapomeň kdo jsě̌, / nezapomeň co chcěs, / nezapomeň odkud přicházíš, / nezapomeň kam jdeš (Don't forget who you are, / don't forget what you want, / don't forget where you come from, / don't forget where you're going). The gulf between the soul-searching of the performers and the self-serving platitudes of the establishment was especially evident towards the end of the Communist era, as encapsulated in Jan Burian's satirical 'Písen strašlivá o tom velkém dialogu, který nastal v Čechách L. P. 1989, ale ne s každým' (A Frightful Song about the Great Dialogue, which Took Place in the Czech Republic in 1989 AD, but Not with Everybody), written earlier the same year. ${ }^{81}$

All three genres analysed in this study exhibit an artistic self-consciousness. This is evidenced, for instance, in songs about both singers and songs, such as 'Pověste ho vejš' and Nohavica's 'Bláznivá Markéta' (Crazy Marketa); songs about music ('Akordy', 'Zradný banjo'[Treacherous Banjo] by K.T.O., 'Tulácké blues' [Wandering Blues] by Tony Linhart a spol. and Merta's 'Nitky' [Strings]); and songs about other forms of creative self-expression (Třešňák's 'Poezie' [Poetry], 'Komedianti nestárnou' [Actors Don’t Grow Old] by Fešáci, Nohavica's 'Darmoděj' and Kryl's 'Potulní kejklírí' [Wandering Jugglers]). This focus on the creative process is accentuated by the repetition of words such as zpívat (to sing) / zpěv (singing) and derivatives, and píseňlpísnička/song (song), cited in fiftythree and forty-four compositions, respectively. Self-doubt and the difficulty of being an artist, especially in the distorted conditions of real socialism, are captured in Merta's 'Konec experimentu' (The End of the Experiment), and 'Kecy' (Twaddle), which begins Jsem špatný člověk, co slouži dobré věci. I Spasitel, který se o pár set let opozdil. I Pokorné sebevědomí jako bývávali světci / kecy, $k e c y, k e c y . .$. (I am a bad person / in the service of good things / A saviour who is a couple of hundred years late / Low in self-esteem, like the saints in days of yore / twaddle, twaddle, twaddle...). The constant problem for song writers such as Merta was that they did not know how far they could experiment before being forcibly silenced.

For some performers, the safest forms of escape from the arbitrary constraints of the censor were fictional nonsense, word play and comedy. Tall stories set to music included Dobeš's 'Hrušky', and Pacifik's 'Velrybářská výprava' (The Whaling Expedition), with the refrain Výprava velrybářská kolem Grónska nezdařila se, I protože nejeli jsme na velryby, ale na mrože (The whaling expedition around Greenland floundered / because we didn't go for whales, but for walruses). Amongst the exponents of word play were Mládek, with his light-hearted critique of socialist naming practices, 'Zkratky' (Abbreviations), and Ladislav Vodička, whose song 'Já tu zemi znám' (I Know this Land) simply lists Czech place names. Plíhal took this art form to a higher metalinguistic level in his 
composition, 'Pojd'me si hrát se slůvky' (Let's Play with Words): Pojd'me si hrát se slůvky / a kreslit jimi malůvky, I i kdyžžádné hvězdy se z nás nestanou, I to jen v zasnění nám pod vičky / ty barvičky, ty slovnícky / aspoň chvili zvonit zůstanou (Let's play with words / and draw childish daubs with them, / even though we won't become stars, / if only in our reveries beneath our eye lids / these colours and word lists / will continue ringing for at least a while). While Mládek may have been the master of paronomasia and other rhetorical devices, Tučný was perhaps even more adept at delivering comic verse. This is clearly illustrated in his self-deprecating number, 'Já tajně cvičím' (I Exercise in Secret) and his popular hit, 'Prodavač' (The Shop Assistant), about selling groceries, sung at break-neck speed (both with Fešáci). ${ }^{82}$ Comic elements offered both performers and audiences a rare respite from the earnestness of officialese, although they posed less of a threat to the status quo than more reflective pieces.

\section{Colloquial Usage in Folk-Spectrum Music}

The songs discussed in this article use a combination of different linguistic registers, according to their subject matter, their target audience, their intended effect and practical linguistic constraints (especially rhyme and scansion). The more cerebral compositions tend to adhere more rigidly to the norms of standard Czech (spisovná čeština), while narrative-style compositions, especially country and tramping songs, frequently adopt the vernacular. The corpus includes numerous colloquial lexical items - too many to enumerate. Suffice it to mention here a few relating to travel: bocman (sailor), bourák (big posh car), čundr (hiking trip), dobytčák (cattle van), mašinfíra (engine driver), perón (railway platform), rajtovat (to ride), šif (river) boat, špacir (walk), vechtr (railway watchman) and veksl (railway points). More significantly, the corpus also contains an extensive range of non-standard morphophonological features, as identified by Charles Townsend and Neil Bermel, amongst others. ${ }^{83}$ The non-standard vocabulary and morphology both help to create a more intimate and informal atmosphere, but it is the latter which defines the essence of the most widely spoken variant of the language - common colloquial Czech (obecná čeština).

The reasons for the choice of the vernacular in song, as in other forms of expression, vary significantly, with different artists having their own preferences. However, the underlying motivation tends to be the same - to make the compositions more authentic, accessible and/or entertaining to the listener. Obecná čeština is the relaxed, unmarked spoken medium employed in the home and in informal settings by most Czechs. In its scripted form it seeks to replicate and reinforce the primacy of the everyday, and, as such, it is ideally suited for sing-alongs and other popular forms of collective cultural experience. Stylistically, it is strongly differentiated from the formality of the Party's rhetoric, and in terms of tenor, it foregrounds the interpersonal dimension of communication. In a song such as 'Ženský ty jsou fajn' (analysed below), the vernacular is appropriate both because of the informal nature of the discourse theme and because the work is intended as an act of shared celebration. The composition is not meant to stimulate the intellect, but rather to evoke an emotional response.

Colloquial Czech is much less appropriate for work which is more consciously poetic and/or appeals principally to the head rather than the heart. Song writers such as Kryl and Merta prefer spisovná čeština because it is considered more refined and elevated, and is seen as more compatible with the expression of complex feelings and ideas. Where Kryl and Merta do use colloquial forms, their purpose is generally to indicate direct or indirect speech, as in 'Bratříčku, zavírej vrátka', Bratřičku, nevzlykej, to nejsou bubáci, / vždyt' už jsi velikej, to jsou jen vojáci (Little brother, don't sob, they're not bogeymen / after all, you're big now; they're just soldiers). Alternatively, it is intended to accentuate the mundane, as in 'Nitky', Prázdný parky za ostnatým drátem / kavárny v rekonstrukci zavřený (Empty parks behind barbed wire, / coffee shops under repair - closed). (Non-standard morphophonological features are underlined.)

\section{i. Common colloquial Czech (obecná čeština)}

As illustrated below, the most frequently occurring non-standard feature in the corpus is the substitution of $-y$ by $-e j$. This is found, above all, in the final position of nominative/accusative masculine singular adjectives (cited in 107 songs). It also occurs in non-grammatical medial position (in 40 songs), and in the modal adverb prej < prý (they say) (14). The other most common nonstandard variant is adjectival and pronominal $-y$ for $-e$, , in the nominative/accusative plural and neuter 
singular (in 79 and 58 songs, respectively). Also worthy of note are the purely phonological prothetic $v$ before initial - $o$ (26 songs); the pronoun tý for té (this/that) in various cases, singular and plural (14); the third-person plural present tense ending $-a j$ for $-a j i$ (13); and the instrumental plural nominal ending - $a m a(9)$.

\title{
MORPHOPHONOLOGICAL VARIATION IN THE CORPUS
}

$\begin{array}{ll}\text { Rank } & \text { Frequency } \\ 1 & 107 \\ 2 & 79 \\ 3 & 58 \\ 4 & 40 \\ 5 & 38\end{array}$

\author{
Grammatical function \\ $-e j$ for $-\hat{y}$ (nom./acc. masc. sing. adj. ending) \\ $-\hat{y}$ for $-\hat{e}$ (nom./acc. plur. adj. and pron. ending) \\ $-y$ for $-e ́ e$ (nom./acc. neut. sing. adj. and pron. ending) \\ $-e j$ for $-y$ (non-grammatical medial position) \\ -ejch for -ých (locative/genitive plur. adj. and pron. ending)
}

There is insufficient space here to exemplify all the features which characterize colloquial usage, but Karásek's 'Ženský ty jsou fajn' exhibits a wide range. Variation is evidenced in the song in several different grammatical categories and parts of speech.

\section{MORPHOPHONOLOGICAL/PHONOLOGICAL VARIATION IN 'ŽENSKÝ TY JSOU FAJN'}

\author{
Adjectives and adverbs \\ neut. nom./acc., sing. \\ fem. nom./acc., plur. \\ krajkový (lace), hotový (ready) \\ fajnový (fine, great), chytrý (intelligent), slabý (weak), dobrý (good), \\ bláhový (foolish) \\ masc. nom., sing. \\ zlej (evil) \\ fem. loc., sing. \\ mužský (male) \\ prej (they say) \\ Verbs \\ first person, plur. \\ third person, plur. \\ infinitive \\ past tense \\ jdem_(let's go), chcem_(we want) \\ daj_-(give), maj_ (have), brečej (cry), myslej (think), slyšej (hear) \\ bejt (to be) \\ moh_(could), řrek_ (said)
}

Pronouns

fem. gen., sing.

od tý doby (from that time)

fem. loc., sing.

na tý Pankráci (at [that] Pankrac)

Conjunctions

$$
d y t^{\prime}<v z ̌ d y t^{\prime} \text { (well) }
$$

Syntactic variation in the song is less obviously indicative of colloquial Czech, due to the effect of poetic licence on word order, but the omission of the auxiliary and the inclusion of the pronoun in $j a$ ve snu vidèl (I saw in a dream) are characteristic of the spoken language. Amongst the lexical colloquialisms employed are ženský for ženy (women), fajnlfajnový for př́jemnýldobrý (fine), basa (nick) for vězení (jail), vajgla (a more slangy variant of vajgly) for nedopalky (butts), moc for velmi (very), mužský for muži (men), jabko for jablko (apple), and furt for pořád (all the time). ${ }^{84}$

\section{ii. Moravian dialects}

Moravian dialects, like obecná čeština, are occasionally used to add local coloration to the songs. Generally, this is done for comic effect, as in Burian and Dědeček's 'Synek z Moravy' (Country Lad from Moravia). This entertaining ditty tells, in Brno dialect, the lament of a young man sent away to Prague by his father. ${ }^{85}$ Amongst the defining morphophonological features of the song are ja su/nésu for já jsem/nejsem (I am/am not); final -é for -ý (masculine nominative, singular) (dospělé [grown-up] etc.); final -é for -aj (second person imperative, singular) (pozné [get to know]); $j u$ for $j i$ (it) (feminine accusative, singular); final -ó for -ou (third person, plural) (žijó [they 
live] etc.); тети for tоти (it) (neuter dative, singular); final -ijó for -í (third person, plural) (mluvijó [they speak] etc.); final -ó for -ou (feminine accusative, singular) (rodnó [native]); and přindu for prijidu (I'll come). The song also contains several lexical items which add to its distinctively Moravian flavour, including šalina (tram), fligna (cheating) and burčák (young half-fermented wine). Elsewhere, Dobeš similarly employs Moravian-Silesian morphophonological features for the purpose of humour; for example, in his account of a dispute between neighbours, 'Hrušky' (Pears): Za našu stodolu hruška maslova / a za ňu stoji dřevjany plot (Behind our barn there's a butter pear-tree / and behind it stands a wooden fence). By contrast, Hutka's 'Morava', cited earlier, largely avoids such marked Moravian variants, save for the third person plurals só for jsou (are) and majó for mají (they have).

\section{Conclusion}

This article has been broad-ranging and ambitious in its scope. It has sought to establish the importance of the contextual dimension of folks-spectrum music, both as a language act and in terms of its historical development. It has also documented the ways in which the authorities strove to limit self-expression, through legal restrictions and secret police surveillance. Moreover, it has identified and evaluated the defining features of a sizeable corpus of songs, with special reference to their themes, motifs, vocabulary and register. The goal in so doing has been to shed further light on a unique cultural phenomenon, which has not always been accorded the status that its importance merits. ${ }^{86}$

There is, of course, no accurate way to measure the challenge posed by the music or the extent to which it inspired or emboldened its listeners. The situation was complex and multifaceted, and the variables are too numerous to be disaggregated. It is, however, possible to draw a number of qualified conclusions. On balance, the folk-spectrum phenomenon (especially as exemplified at folk concerts and tramp gatherings) was an unwelcome distraction to the Communist regime. It may have served partly as a release valve, but it occupied an uncomfortable position in the grey zone between compliance and confrontation. The vast resources invested in monitoring performers and fans testify to the scale of the Party's concern over the music's potentially subversive influence. It was not just that the content of the songs eschewed engagement with the officially approved authoritative discourse, or that their tone tended to be pessimistic or maudlin. Nor was it simply that people adopted modes of behaviour deemed incompatible with socialist society. It was both of these factors, together with the interactional aspect of the folk-spectrum experience. The music provided a medium and forum for the articulation of alternative views.

The popularity of folk-spectrum music is beyond dispute. It may not have enjoyed the same appeal as pop or rock music, but it attracted large numbers of enthusiasts searching for alterity and selffulfilment. Perhaps the most telling proof of its success was the role that it played during the Velvet Revolution. Not for nothing did folk-style musicians find themselves centre stage when it came to rallying the crowds on Václavské náměstí (Wenceslas Square) and Letenská pláň (Letná Plane) in November 1989. Ivo Jahelka, in his anthem about the end of Communism, 'Veselá revoluce' (Merry Revolution), alluded to the unique contribution of folk-style music when he sang My jsme ta veselá revoluce, I písničky jsou naše rezoluce, I slova jak květiny vzešla z pravdy, I píšeme dějiny už doopravdy (We are that merry revolution / songs are our resolution, / words like flowers have emerged from the truth / we are truly writing history). Folk-spectrum music may not have actually (rewritten history, but it made a difference to people's lives. For some, it strengthened their resolve not to acquiesce; for others, it provided a romantic or sentimental escape from the strictures and practices of real socialism.

The fact that the music has retained so much of its appeal to this day is in many ways surprising, and raises a number of intriguing questions. ${ }^{87}$ Is its enduring popularity partly attributable to the continuity that it offers with the pre-Communist and/or Communist past? Is there more to it than nostalgia for the intensity of the aesthetic and extra-aesthetic experiences of one's youth? Has Fox's 'Loss' somehow been reconfigured in a paradoxical way? Does the music still resonate more with those who are dissatisfied with the status quo? Has the largely apolitical nature of the songs contributed to their accessibility? 
It will be fascinating to see whether the work of Kryl, Merta, Nohavica, Spirituál kvintet, Daněk, Tučný, Křest'an and others is still played in, say, thirty years' time. If so, it would suggest that, despite the constraints of the regime, artists in normalization Czechoslovakia succeeded in producing a cultural artefact which has transcended ideological and generational differences.

\section{Notes}

${ }_{1}$ For more on perlocution, see J. L. Austin, How to Do Things with Words, Oxford, 1962.

${ }_{2}$ See M. A. K. Halliday, The Essential Halliday (chapter 12: 'Metafunctions'), London and New York, 2009, and M. A. K. Halliday and Ruqaiya Hasan, Language, Context, and Text: Aspects of Language in a SocialSemiotic Perspective, Oxford, 1989.

${ }_{3}$ According to a survey conducted by A. Opekar and J. Vlček in 1984, cited by Miroslav Vaněk, Byl to jenom rock ' $n$ ' roll?, Prague, 2010, p. 42, country/folk was the preferred genre of $12 \%$ of parents of children aged 13 to 15 , third only to pop and brass band music.

${ }_{4}$ Attempts to extrapolate 'meaning' from the sounds of music (notation, vocalization, instrumentation, structure, and so on) tend to be too subjective to be of much value.

${ }_{5}$ John Connell and Chris Gibson, Sound Tracks: Popular Music, Identity and Place, London and New York, 2003 , p. 89.

${ }_{6}$ Robert Owen Gardner, 'Introduction: Spaces of Musical Interaction: Scenes, Subcultures and Communities', in Norman K. Denzin (ed.), Studies in Symbolic Interaction, 35, Bingley, 2010, pp. $71-77$ (p. 71).

7 Porta - one of the very few cultural events of its type to survive 1968 (albeit under the strict control of Socialistický svaz mládeže [the Socialist Union of Youth] and in changing locations) - was established as a country and western and tramping competition in Ústí nad Labem in 1967, but folk was added in 1968, despite opposition from some country and tramping 'purists'.

\& See, especially, Jiř́na Šiklová, 'The "Gray Zone" and The Future of Dissent in Czechoslovakia', Social Research, 57, 1990, 2, pp. 347-63.

9 I am indebted to the staff at Siwiecova Central Research Centre for their help in accessing relevant files. ${ }_{10}$ General studies of folk music include Přemysl Houda, Intelektuální protest, nebo masová zábava? Folk jako společenský fenomén v době tzv. normalizace, Prague, 2014; Helena Pavličíková, 'The History of Czech Modern Folk Music', Musicologica Olomucensia V, 2000, pp. 113-22; Josef Prokeš, Ceská folková píseň v kontextu 60.-80. let 20. století, Brno, 2011, and Vladimír Vlasák, Folkaři. Báječni muži s kytarou, kteř́ psali dějiny, Řitka, 2008.

${ }_{11}$ See Jan Pohunek, 'A Century of Czech Tramping', Folklorica, 16, 2011, pp. 19-41.

12 Less has been written about country music, although Jiř́ Vondrák and Fedor Skotal, Legendy folku \& country, Brno, 2004, offer a comprehensive overview of the development of folk-spectrum music as a whole. (The book is closely linked to the thirteen-part television series of the same name, directed by Jiří Vondrák and produced by Česká televize in 2001.) Also noteworthy in the context of country and tramping music is Don Sparling and Tomáš Pospišil, 'Thirteen Ways of Looking at America', Sborník prací Filozofické fakulty Brněnské univerzity Studia minora Facultatis philosophicae Universitatis Brunensis, S 7, 2001, pp. 73-84.

${ }_{13}$ Devotees of more intellectual folk forms may object to the inclusion of folk song alongside tramping and country music, but they are likely be equally dismissive of more popular styles of folk.

${ }_{14}$ L. P. Hartley, The Go-Between, London, 1953.

15 Kubišová, whose work is perhaps best categorized as pop-folk, won the music award Zlatý slavík (Golden Nightingale), in both 1968 and 1969.

16 See Pohunek, 'A Century of Czech Tramping', p. 22.

17 See Vondrák \& Skotal, Legendy folku \& country, p. 11.

${ }_{18}$ For an overview of the four organizations, see Bob Hurikán and Stanislav Motl, (eds), Dějiny trampingu, Prague, 1990; Petr Jehlička, 'Indians of Bohemia: The Spell of Woodcraft on Czech Society 1916-2006', pp. 112-30, in Diethelm Blecking and Marek Waic (eds), Sport - Ethnie - Nation: Zur Geschichte und Soziologie des Sports in Nationalitatenkoflikten und bei Minoritaten, Baltmannsweiler, 2008; Claire E. Nolte, The Sokol in the Czech Lands to 1914: Training for the Nation, New York, 2002, and Antonín Benjamin Svojsík, Základy junáctví: Návod pro výchovu české mládeže na základě systému sira R. Baden-Powella 'Scouting for boys' a za laskavého přispění četných odbornikỉ, Prague, 1991.

19 Petr Jehlička and Matthew Kurtz, 'Everyday Resistance in the Czech Landscape: The Woodcraft Culture from the Hapsburg Empire to the Communist Regime', East European Politics and Societies and Cultures, 27, 2013, 2, pp. 1-39 (p. 12).

20 See Vondrák \& Skotal, Legendy folku \& country, p. 11.

${ }_{21}$ See Paulina Bren, 'Weekend Getaways: The Chata, the Tramp and the Politics of Private Life in Post-1968 Czechoslovakia', in David Crowley and Susan E. Reid (eds), Socialist Spaces: Sites of Everyday Life in the Eastern Bloc, Oxford and New York, 2002, pp. 123-40 (p. 129).

${ }_{22}$ Sparling and Pospísili, 'Thirteen Ways of Looking at America', p. 78.

${ }_{23}$ The term bigbít was preferred to rock ' $n$ ' roll because it sounded less decadent and American. See Vaněk, Byl to jenom rock ' $n$ ' roll?, p. 25 (note 7).

${ }_{24}$ Tony Linhart merits special recognition for his contribution to the resurrection and development of tramping music.

${ }_{25}$ Until then, the releases had been mainly traditional tramping songs from the First Republic.

${ }_{26}$ The album Rosa na kolejich sold over a quarter of a million copies.

${ }_{27}$ The distinctions between the two pursuits are discussed in detail by Bren, 'Weekend Getaways', pp. 123-40. 
${ }_{28}$ See Roman Jakobson, 'Closing Statement: Linguistics and Poetics', in T. A. Sebok (ed.), Style in Language, Cambridge, MA, 1960, pp. 350-83 (pp. 353-54).

${ }_{29}$ Pavličíková, 'The History of Czech Modern Folk Music', p. 114.

${ }_{30}$ Osvobozené divadlo (1926-38) was an iconoclastic left-orientated avant-garde Prague theatre. Suchý and Šlitr were a double-act in the late 1950s and 1960s, who contributed hugely to the development of popular music and theatre.

${ }_{31}$ Seeger's hitherto virtually unknown five-string banjo attracted particular attention, and Czech musicians went to exhaustive efforts to make or buy one. (See private correspondence with Bohuslav Rychlík.)

${ }_{32}$ See Pavličíková, 'The History of Czech Modern Folk Music', p. 119.

${ }_{33}$ See Prokeš, Česká folková písě̌, p. 23.

${ }_{34}$ The repertoire of Spirituál kvintet embraces other genres, especially spirituals and traditional Western folk.

${ }_{35}$ Andrtová-Voňková was born Reschová, and performed under the name Voňková until her second marriage on 31 May 1985.

${ }_{36}$ Renamed Třináct na houpačce (Thirteen on a Swing) in 1966 and Čtrnáct na houpačce (Fourteen on a Swing) in 1968.

${ }_{37}$ The album Bratríčku, zavirej vrátka sold 125,000 copies 'under the counter' in two months in 1969, and was seen as a symbol of resistance.

${ }_{38}$ According to Karel Janovský-Drážd’anský, cited in Vlasák, Folkaři, p. 251, Kryl was the most popular personality on Svobodná Evropa.

${ }_{39}$ Nohavica was unusual in that he tended to look northwards and eastwards, for example to the work of Bulat Okudzhava and Vladimír Vysotsky, for his sources of inspiration. See Vlasák, Folkaři, p. 103.

${ }_{40}$ Prokeš, Česká folková písě̌, p. 35. Prokeš’s study involves in-depth analysis of 'exemplars' by each of a series of influential folk artists.

${ }_{41}$ See, for example, Katrina Clark, The Soviet Novel: History as Ritual, Chicago, IL, 1981, and William W. Savage Jr., The Cowboy Hero: His Image in American History and Culture, Norman, OK and London, 1979.

${ }_{42}$ It is not always clear whether 'interpretations' which deviated from the original did so deliberately or merely reflected inadequate linguistic skills.

${ }_{43}$ For example, journeys to foreign parts, such as Mexico, or even the much nearer Matterhorn, merely highlighted the limited opportunities for Czechoslovak citizens to travel to non-Communist countries.

${ }_{44}$ Matuška, who appeared with K.T.O. from 1972, was one of the stars of the 1960 s, although he is perhaps more associated with pop music than country. He won the Zlatý slavík award in 1962 and 1967, but became a 'non-person' in 1986 when he chose to emigrate.

45 Tučný, whose name appropriately (in view of his size) means 'Fatty', was hugely important not only as a solo artist, but also for his contribution to the groups Rangers, Greenhorns, Fešáci and his own band, Tučňáci (Penguins).

${ }_{46}$ Vondrák \& Skotal, Legendy folku \& country, p. 222.

47 Aaron A. Fox, 'The Jukebox of History: Narratives of Loss and Desire in Country Music', Popular Music, 11, 1992, 1, pp. 53-72 (p. 54).

${ }_{48}$ See Vaněk, Byl to jenom rock 'n' roll?, p. 342.

${ }_{49}$ All translations are my own, and attempt to convey the sense of the original, rather than to 'interpret' the meaning of the words or to reproduce rhyme or scansion. It is, however, not always possible to capture the nuances of the original; for instance, 'mřržze' in Velinský's song may refer either to the security grating frequently found on ground-floor windows or to, say, prison bars.

${ }_{50}$ Gustáv Husák was General Secretary of the Communist Party of Czechoslovakia from 1969 to 1987, and President of Czechoslovakia from 1975 to 1989.

51 Vaněk, Byl to jenom rock ' $n$ ' roll?, pp. 392-93.

${ }_{52}$ See Vlasák, Folkaři, p. 287.

53 The most authoritative study of Šafrán is Přemysl Houda, Šafrán. Kniha o sdružení písničkářù, Prague, 2008.

${ }_{54}$ Hutka, Veit and Třešnák were amongst the signatories of Charter 77.

${ }_{55}$ See Houda, Intelektuální protest, nebo masová zábava?, pp. 135-60 and 161-81, and Vladimír Kouřil, Jazzová sekce v čase a nečase. 1971-1986, Prague, 1999.

${ }_{56}$ Archiv bezpečnostních složek (hereafter, ABS), 728753_MV_1_6_0027-1.

57 ABS, 6777997_MV_01_01_0032-1.

${ }_{58}$ ABS, 6777997_MV_01_01_0042-1.

${ }_{59}$ ABS, V_5147_HK_007> V_5147_HK_026.

60 ABS, V_5147_HK_014.

61 ABS, 808320_MV_0018.

62 ABS, 808320_MV_0090.

${ }_{63}^{6} \mathrm{He}$ spent much of his time in the 1980 s writing for and editing animated films.

${ }_{64}$ ABS, 808420_MV_1_2_0006-1.

65 ABS, 808420_MV_2_2_0012-1.

66 ABS, 964520_MV_0011.

${ }_{67}$ No attempt is made here to deconstruct their morphological and syntactic composition. For an analysis of the frequency and arrangement of the word forms (nouns, adjectives, pronouns, etc.) of a small corpus of selected folk songs, see Prokeš, Česká folková písě̌, pp. 120-26.

68 Texts were taken from various different sources, including 'karaoke.cz', 2014. Available at $<$ http://www.karaoketexty.cz/>. Release dates are only stated where especially relevant, because they provide little indication of when a song was written or first performed.

69 In some cases, such as 'Náklad'ák' ([The Lorry] < 'Banks of the Ohio'), the 'interpretations' merely maintained the tune of the original; in others, such as 'Ved' mě dál cesto má' ([Lead Me on, My Road] < 'Country Road'), the content bore a closer resemblance to their source.

${ }_{70}$ Laurence Anthony, AntConc, 2016. Available at <http://www.laurenceanthony.net/software.html $>$. 
${ }_{71}$ For a discussion of Czech attitudes to feminism, see, for example, Marianne A. Ferber and Phyllis Hutton Raabe, 'Women in the Czech Republic: Feminism, Czech Style', International Journal of Politics, Culture, and Society, 16, 2003, 3, pp. 407-30.

${ }_{72}$ See James Clifford, Routes: Travel and Translation in the Late Twentieth Century, Cambridge, MA, 1997. 73 Sparling and Pospíšil, 'Thirteen Ways of Looking at America', pp. 7-8, have illustrated in detail how the natural world of the Czech countryside expands to encompass American reality.

${ }_{74}$ Ibid., p. 9.

75 The Woodcraft League of Czechoslovakia, founded as Zálesácká liga československá in 1922, was known as Liga lesní moudrosti (The League of the Wisdom of the Wood) from 1923 to 1929.

${ }_{76}$ Ivan Mládek's work is difficult to classify, although it is broadly country-style, with elements of Dixieland. 'Jožin z bažin' has become known even in other languages, and has been used to parody both the ex-Polish prime minister, Donald Tusk, and President Putin.

${ }_{77}$ Antonín Koniáš was a Jesuit priest implacably opposed to the Czech reformation, and associated with the burning of books.

${ }_{78}$ An StB agent actually found a reference to Havlíček as 'Havel' in his collected works. See Honza Dědek, 'NEJ HITY: Hutkovi bylo líto Havla. Tak mu napsal píseň', Lidovky.cz, 13 July 2011. Available at <http://www.lidovky.cz/nej-hity-hutkovi-bylo-lito-havla-tak-munapsal-pisen-fy2-

/kultura.aspx?c=A110511_113241_ln_kultura_pks>.

${ }_{79}$ For a detailed discussion of this theme, see Zdeněk R. Nešpor, 'Česká folková hudba 60.-80. let 20. století v pohledu sociologie náboženství’, Sociologický časopis / Czech Sociological Review, 39, 2003, 1, pp. 79-97.

80 The inclusion of the forbidden English-language refrain, Say no to the devil, merely accentuated the unacceptability of Karásek to the authorities.

${ }_{81}$ The title is inspired by those found in broadside ballads, based on the combination of a momentous event, together with the place and the year where it happened.

${ }_{82}$ As a trained shopkeeper, Tučný was well qualified to sing about food, but the irony of the lyrics was not lost on him or his audience, given the shortage of consumer products and the poor service in Czech shops.

${ }_{83}$ Charles E. Townsend, A Description of Spoken Prague Czech, Columbus, OH, 1990, and Neil Bermel, Register Variation and Language Standards in Czech, LINCOM Studies in Slavic Linguistics, 13, Munich, 2000.

${ }_{84}$ The song also includes some conspicuously high-style features, such as the words bohorovnost (haughtiness) and emancipovat (to emancipate), and the bookish morphological forms dočisti se (to learn) and nad tvory (over creatures).

${ }_{85}$ The humour derives at least partly from the fact that neither singer was originally from Moravia.

${ }_{86}$ Even authoritative accounts of opposition to normalization have largely ignored it. See, for example, Milan Otáhal, Opoziční proudy v české společnosti 1969-1989, Prague, 2011.

${ }_{87}$ Czech radio stations, such as Ceský Impuls, Country Radio and Rádio Blaník, continue to offer a heavy diet of folk, tramping and country music from the 1960 s to the 1980 s. In a poll of the Czechs' 100 favourite songs, conducted in 2006, 41 pre-dated 1990, including 11 from the 60s, 5 from the 70s and 22 from the 80s. Eleven of the greatest hits fall broadly within the description of folk-spectrum music. See Radek Bureš a Honza Vedral, 'Ta naše písnička česká aneb 100 nejlepších hitů, iDnes, 3 March 2006. Available at <http://kultura.idnes.cz/tanase-pisnicka-ceska-aneb-100-nejlepsich-hitu-f37-/filter.aspx?c=A060303_142630_filter_kot>. 